\title{
Riots, Revelries, and Rumor: Libertinism and Masculine Association in Enlightenment London
}

\author{
Jason M. Kelly
}

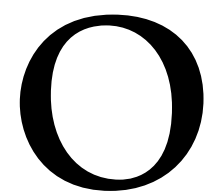

n Friday, 30 January 1734/5, eight men met each other at the Golden Eagle Tavern on Suffolk Street in the West End. All but one of them were members of the Society of Dilettanti, a group formed three years earlier by gentlemen who had met each other on the Grand Tour. Some were nobles, such as Charles Sackville, Earl of Middlesex, but all of them were well known, both in Italy and London, for their youthful indulgences. ${ }^{1}$ That Friday evening was already charged with popular political tension, since it was the

Jason M. Kelly is assistant professor of British history at Indiana University-Purdue University at Indianapolis. This article is part of a larger study of the Society of Dilettanti, which investigates sociability, archaeology, and national identity in Enlightenment Britain. Research funding for this article was generously provided by Keck Foundation and Andrew W. Mellon Foundation fellowships for research at the Huntington Library, by the Kanner Fellowship in British Studies for research at the William Andrews Clark Memorial Library, by grants from the University of California Regents and the University of California, Santa Barbara History Associates, and by fellowships from Indiana University's New Frontiers in the Arts and Humanities program and the President's Council on International Programs. For their wonderful suggestions in preparing this article, the author would like to thank Ellen Arnold, Ann Bermingham, Helen Berry, Anna Clark, Joost Fontein, Anita Guerrini, Danna Kostroun, J. Sears McGee, Erika Rappaport, audience members and fellow panelists at the 2005 American Society for Eighteenth-Century Studies Conference, and the anonymous readers at the Journal of British Studies.

${ }^{1}$ The other men present that night were Simon, Viscount Harcourt; Gustavus Hamilton, Viscount Boyne; William Strode; Sewallis Shirley; James Gray; and William Denny. The only man at the tavern not a member of the Dilettanti was John Murray. Arthur Smyth to Joseph Spence, 7 February 1734/ 5, ms. letter, opposite 394 in Huntington Library Rare Books 131213. John Timbs (Clubs and Club Life in London [London, 1872], 24) quotes Horace Walpole, who suggested that William Stanhope, Lord Chesterfield's younger brother, was also present. However, he was surely mistaken in this assumption, because none of the participants or their friends ever mentioned Stanhope. Furthermore, both the textual and visual sources only recognize eight participants. Middlesex to Spence, 9 February 1734/5 (ms. letter, opposite 395 in Huntington Library Rare Book 131213), specifically stated that there were eight participants. John Murray's brothers, William and George, were ardent Jacobites. Murray's participation in the celebrations no doubt lent an air of controversy to the assembly.

Journal of British Studies 45 (October 2006): 759-795

(C) 2006 by The North American Conference on British Studies.

All rights reserved. 0021-9371/2006/4504-0003\$10.00 
anniversary of the martyrdom of Charles $\mathrm{I}^{2}$ On that night, this group of young men acted out, started a bonfire, and engaged in loud and angry political discourse with a "mob," setting off rumors and gossip in London. This incident, seemingly a drunken folly, can be compared to a scandal decades later, in 1763, that also involved prominent members of the Dilettanti and that sparked rumor and gossip as well.

In the earlier event, in all likelihood, the men were warming up for a weekend of revelry to be capped by their dinner at the Society of Dilettanti meeting on Sunday, 2 February. They certainly got carried away with their drinking that evening, and it is at this point that the historical record-and, we can imagine, their personal memories-becomes a bit fuzzy. What we can be sure of is that, by the end of the night, the men had started a bonfire in the square outside the tavern, attracted and insulted a crowd, initiated a riot, and caused $£ 100$ in damage to the tavern. ${ }^{3}$ Their actions created a furor in the press, so much so that on 9 February Middlesex wrote to his fellow Dilettante Joseph Spence that "it has been the talk of the Town and the Country and small beer and Bread \& Cheese to my friends the Garretteers in Grubstreet for these few days past." "The Gentleman's Magazine provided a succinct and popular version of the story that gives some important clues about the events and their consequences: "Friday, Jan. 30. Some young Noblemen and Gentlemen at a House in Suffolk Street, called themselves the Calve's Head Club; dress'd up a Calf's Head in a Napkin, and after some Huzzas threw it into a Bonfire, and dipt Napkins in their red Wine, and wav'd them out a Window. The mob had strong Beer given them, and for a Time hallood as well as the best; but taking Disgust at some Healths propos'd, grew so outragious, that they broke all the Windows, and forc'd themselves into the House, but the Guards being sent for, prevented further Mischief." ${ }^{5}$ One wonders what kinds of rumors circulated through the mob that day as these young men intentionally built a bonfire - an action that they knew would inevitably draw a crowd.

The Calves-Head incident, while interesting in and of itself, takes on added significance when considered with another public debacle involving several prominent members of the Society of Dilettanti, including Francis Dashwood, the Earl of Sandwich, and the politician John Wilkes. It took place nearly thirty years later, but it too was surrounded by rumor, gossip, and a consistent embellishing of the facts. On 22 January 1763, the Public Advertiser announced the sale of a new print titled Secrets of a Convent (fig. 1). ${ }^{6}$ In the print, Dashwood, dressed in a monk's robe, kneels before an altar to the Medici Venus. Over the next several months, the significance of this print became increasingly apparent to the London reading public, which recognized the content as a reference to the rumored "Monks of Medmenham Abbey." These "monks" were Dashwood's friends, whom he hosted at the ruins of Medmenham Abbey, where they supposedly drank heavily

\footnotetext{
${ }^{2}$ The church canonized Charles I on 19 May 1660 at the Convocation of Canterbury and York.

${ }^{3}$ Grub-Street Journal, no. 267 (6 February 1734/5): 1r.

${ }^{4}$ Middlesex to Spence, 9 February 1734/5.

${ }^{5}$ Gentleman's Magazine, 5 February 1734/5, 105. For some supplementary information, see London Magazine; or, Gentleman's Monthly Intelligencer, February 1734/5, 97.

${ }^{6}$ Public Advertiser, no. 8806 (22 January 1763): 2r. On Darly, see Shearer West, "The Darly Macaroni Prints and the Politics of the 'Private' Man" in Eighteenth-Century Life 25, no. 2 (2001): 107-82.
} 


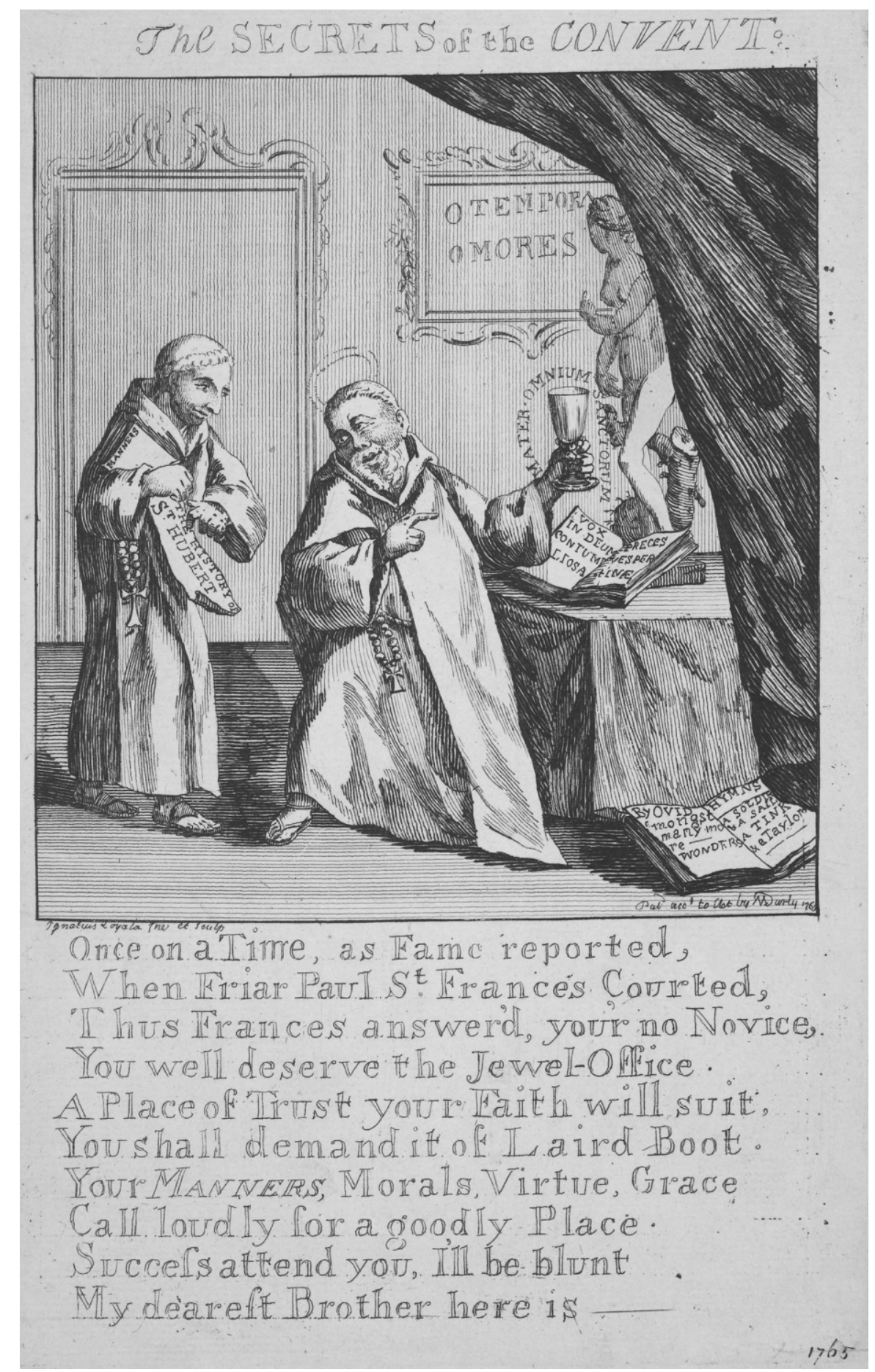

Figure 1-Secrets of a Convent, 1763. (C) by the Trustees of the British Museum. 
and engaged in anti-Christian rituals and frolics with prostitutes. ${ }^{7}$ In the print rested many clues to the political storm and sexual scandals of 1763 , one that pitted Dilettanti members, such as the Earl of Bute, the Earl of Sandwich, George Grenville, Dashwood, and Robert Wood, against the pamphleteering of former friends John Wilkes and Charles Churchill, who were not members of the society. ${ }^{8}$ The supposed participation in Medmenham activities by several of these men would be exposed to a morally aghast but voyeuristically titillated public, damaging the men's political careers.

The highly political turmoil of the 1760s-especially the return of John Wilkes from exile in 1768-69-has been well studied by scholars such as George Rudé, John Brewer, Kathleen Wilson, Anna Clark, and Arthur Cash. ${ }^{9}$ But the events of 1763 still leave the historian with a number of questions. In particular, what did the political skirmishes of 1763 mean to the London public, and how did the public initially interpret these events? What effects did Wilkes's revelations about Dashwood's monks have on the reception and circulation of Wilkite political rhetoric and symbolism, and how did this change during the early months of Wilkite agitation? Answering these questions entails understanding the gossip and rumors that circulated through the coffeehouses, taverns, and markets. In fact, many of the accusations from each side appealed to public "knowledge" embedded in popular memory through the practice of gossip and the circulation of this knowledge in print. $^{10}$

Comparing the Calves-Head incident from 1734/5 and Wilkes's exposure of the "Medmenham Monks" in 1763 in detail helps formulate a historical anthropology of gossip and rumor and offers several insights into the nature of London social life and political controversy during the Enlightenment. First, the histories of the Calves-Head Club and Medmenham Monks show how the practices of gossip and rumor converged with, diverged from, and helped articulate discourses about class and masculinity in eighteenth-century London. In a period in which "polite association" was increasingly challenging "masculine libertinism" as a symbol of status, the practices of rumor and gossip were important to negotiating the

\footnotetext{
${ }^{7}$ The Medmenham brotherhood has been a subject of scholarly, fictional, and even conspiratorial discussion for over two centuries. The best, but still imperfect, accounts include Francis Dashwood, The Dashwoods of West Wycombe (London, 1987); Wendy Frith, "Sexuality and Politics in the Gardens at West Wycombe and Medmenham Abbey," in Bourgeois and Aristocratic Cultural Encounters in Garden Art, 1550-1850, ed. Michel Conan (Washington, DC, 2002), 285-309; Betty Kemp, Sir Francis Dashwood: An Eighteenth Century Independent (New York, 1967); Teresa Miller Ross, "Franklin, Dashwood, and the Mad Monks of Medmenham" (PhD thesis, University of Texas at Austin, 1977); and Julie Peakman, Lascivious Bodies: A Sexual History of the Eighteenth Century (London, 2004), 103-28.

${ }^{8}$ William Cobbett and Thomas Howell, Cobbett's Complete Collection of State Trials and Proceedings, vol. 19 (London, 1809-26), 1166-68.

${ }^{9}$ John Brewer, Party Ideology and Popular Politics at the Accession of George III (Cambridge, 1976); Arthur Cash, The Scandalous Father of Civil Liberty (New Haven, CT, 2006); Anna Clark, Scandal: The Sexual Politics of the British Constitution (Princeton, NJ, 2004); Kathleen Wilson, The Sense of the People: Politics, Culture, and Imperialism in England, 1715-1785 (Cambridge, 1995); George Rudé, Wilkes and Liberty: A Social Study of 1763 to 1774 (Oxford, 1962).

${ }^{10}$ Historians have recently begun to revise their assumptions about popular literacy in the early modern period, emphasizing a more widespread literacy and a close relationship between print and oral culture. See, e.g., Jonathan Barry, "Literacy and Literature in Popular Culture: Reading and Writing in Historical Perspective," in Popular Culture in England, c. 1500-1850, ed. Tim Harris (New York, 1995), 69-94, and Adam Fox, Oral and Literate Culture in England, 1500-1700 (Oxford, 2000).
} 
boundaries of proper conduct. Second, these two events offer insight into how ideas about class and masculinity shaped eighteenth-century associational life. In the "clubbable" world that was eighteenth-century London, individuals' reputations-and the gossip and rumor that surrounded them—affected their association with the multiple organizations of which they were members. This meant that the reputations and, consequently, the activities of any one club or society-even those with fundamentally different purposes-could be influenced by that of the others. Because of this, gossip and rumor in any sector of one's life had the possibility of wide-ranging consequences for the "associational world" of eighteenth-century London. ${ }^{11}$ Thus, a reputation for associating with the Calves-Head Club or the Medmenham Monks influenced both individual and corporate reputations within the Society of Dilettanti.

Anthropologists have long concerned themselves with the social and cultural implications of gossip and rumor. As such, their studies provide historians with a set of tools to talk about these forms of linguistic exchange. First, there is a difference between gossip- "informal, private communication between an individual and a small, selected audience concerning the conduct of absent persons or events" - and rumor - "unsubstantiated information, true or untrue, that passes by word of mouth, often in wider networks than gossip." ${ }^{12}$ Second, anthropologists have shown that gossip and rumor can function in multiple ways. In the 1960s, Max Gluckman argued that gossip functions to solidify a group's unity while distinguishing it from other groups. ${ }^{13}$ Gossip can monitor group boundaries while reinforcing social norms. ${ }^{14}$ This point of view seems to be supported by the research of E. P. Thompson and other historians. ${ }^{15}$ Conversely, Robert Paine has suggested that, while gossip can reinforce group identity, it functions in a much more in-

\footnotetext{
${ }^{11}$ Peter Clark, British Clubs and Societies, 1580-1800: The Origins of an Associational World (Oxford, 2000).

${ }^{12}$ Sally Engle Merry. "Rethinking Gossip and Scandal," in Toward a General Theory of Social Control, vol. 1, ed. Donald Black (Orlando, FL, 1984), 275; Pamela J. Stewart and Andrew Strathern, Witchcraft, Sorcery, Rumors, and Gossip (Cambridge, 2004), 38-39.

${ }^{13}$ Max Gluckman, "Psychological, Sociological and Anthropological Explanations of Witchcraft and Gossip: A Clarification," Man 3, no. 1 (1968): 20-34.

${ }^{14}$ In so doing, gossip and rumor can also serve as a means of resistance to imposed political, social, and cultural structures. See, e.g., Ranajit Guha, Elementary Aspects of Peasant Insurgency in Colonial India (Delhi, 1983); Rudrangshu Mukherjee, “'Satan Let loose upon Earth': The Kanpur Massacres in India in the Revolt of 1857," Past and Present, no. 128 (1990): 92-116; Patricia A. Turner, "Ambivalent Patrons: The Role of Rumor and Contemporary Legends in African-American Consumer Decisions," Journal of American Folklore 105 (1992): 424-41.

${ }^{15}$ Gossip and rumor seem to have played an important role in the formation of class consciousness as well as the maintenance of the "moral economy" in the eighteenth century. See E. P. Thompson, The Making of the English Working Class (New York, 1966), and "The Moral Economy of the Crowd in the Eighteenth Century," in Customs in Common (London, 1993), 185-258. The work of other eighteenth-century scholars suggests similar implications. See such varied examples as Cindy McCreery, "Keeping up with the Bon Ton: The Tête-à-Tête Series in the Town and Country Magazine," in Gender in Eighteenth-Century England: Roles, Representations, and Responsibilities, ed. Hannah Barker and Elaine Chalus (London, 1997), 207-29; Edith B. Gelles, "Gossip: An Eighteenth-Century Case," Journal of Social History 22, no. 4 (1989): 667-84; Robert Darnton, The Literary Underground of the Old Regime (Cambridge, MA, 1982); George Rudé, Paris and London in the Eighteenth Century (New York, 1971).
} 
dividualistic manner. ${ }^{16}$ In his view, gossip is selfish: "It is the individual and not the community that gossips. What he gossips about are his own and others' aspirations and only indirectly the values of the community." ${ }^{\prime 7}$ Many anthropologists have turned away from such functionalist approaches to gossip and rumor. ${ }^{18}$ Following Erving Goffman, they have emphasized that gossip is a social drama, arguing that it is one of the many everyday activities performed by individuals within a community. ${ }^{19}$ In this sense, gossip has a formulaic narrative, with its own culturally determined rules - a linguistic mode and social practice that skirts the boundaries of the public/private divide and the distinction between polite and impolite speech. Patricia Meyer Spacks has thought-provokingly and eloquently examined this ambiguity in her analysis of gossip in eighteenth-century literary productions. ${ }^{20}$

Scholars such as Laura Gowing, Steve Hindle, and Bernard Capp have shown how women used gossip and rumor to assert their authority and interests in early modern England. ${ }^{21}$ Using sources ranging from prescriptive literature to court documents, these historians have demonstrated that gossip was a form of linguistic exchange that allowed women to elide patriarchal structures. While early modern gossip and rumor relied on familial relations, neighborhood networks, and communal association, these practices could give women, both individually and collectively, a powerful voice within the familial sphere and the local community. Because of this, recent scholarship has concentrated on patterns of female gossip-largely ignoring the nature and extent of male gossip. This emphasis, however, overlooks a powerful force in early modern England, for men also participated in networks of gossip and rumor, which they used to work out the boundaries of masculinity. In fact, understanding how men participated in these practices allows the historian to understand a key element of early modern gender relations and ideologies. ${ }^{22}$

This article extends these approaches by showing how the functions, forms, and practices of gossip and rumor were related to eighteenth-century gender and class

${ }^{16}$ Robert P. B. Paine, "What Is Gossip About? An Alternative Hypothesis," Man 2, no. 2 (1967): 278-85.

${ }^{17}$ Ibid., 280-81.

${ }^{18}$ See, e.g., the early critique of both Gluckman and Paine in Peter J. Wilson, "Filcher of Good Names: An Enquiry into Anthropology and Gossip," Man 9, no. 1 (1974): 93-102.

${ }^{19}$ Roger D. Abrahams, "A Performance-Centered Approach to Gossip," Man 5, no. 2 (1970): 290-301; Jörg R. Bergmann, Discreet Indiscretions: The Social Organization of Gossip, trans. John Bednarz Jr. (New York, 1993); Wolf Bleek, "Witchcraft, Gossip, and Death: A Social Drama," Man 11, no. 4 (1976): 526-41; Erving Goffman, The Presentation of Self in Everyday Life (Garden City, NY, 1959).

${ }^{20}$ Patricia Ann Meyer Spacks, Gossip (New York, 1985).

${ }^{21}$ Laura Gowing, Domestic Dangers: Women, Words, and Sex in Early Modern London (Oxford, 1996); Steve Hindle, "The Shaming of Margaret Knowsley: Gossip, Gender and the Experience of Authority in Early Modern England," Continuity and Change 9, no. 3 (1994): 391-419; Bernard Capp, When Gossips Meet: Women, Family, and Neighborhood in Early Modern England (Oxford, 2003).

${ }^{22}$ For the significance of masculinity to the field of gender studies, see John Tosh, "What Should Historians Do with Masculinity? Reflections on Nineteenth-Century Britain," History Workshop Journal 38, no. 1 (1994): 179-202. Important studies of masculinity in the early modern period include Michèle Cohen, Fashioning Masculinity: National Identity and Language in the Eighteenth Century (London, 1996); Philip Carter, Men and the Emergence of Polite Society: Britain, 1660-1800 (London, 2001); Tim Hitchcock and Michèle Cohen, eds., English Masculinities, 1660-1800 (London, 1999); Anthony Fletcher, Gender, Sex, and Subordination in England, 1500-1800 (New Haven, CT, 1995); Elizabeth A. Foyster, Manhood in Early Modern England: Honour, Sex and Marriage (London, 1999), Randolph Trumbach, Sex and the Gender Revolution, vol. 1 (Chicago, 1998). 
expectations. To understand this, it is necessary to briefly summarize the theoretical and methodological foundations of my argument. With the functionalists, I recognize that gossip and rumor can, and often do, function to preserve social structures-although not necessarily rigid ones. In fact, as the case studies below reveal, gossip and rumor, as modes of communication, fed into tensions over social status and gender ideals, providing participants with a discursive space to struggle for meaning. Earlier anthropologies have suggested that the rituals of gossip and rumor preserve normative social values. However, while participants in the ritual of gossip (both actors and audience) assume that their rhetorical positions reflect the normative standards of the society in which they operate, they usually ignore the variety and complexity of social norms, relationships, and practices. But the disjunction between their multiple rhetorical positions often leads to tensions and even moments of crisis. ${ }^{23}$ For instance, as demonstrated by Anthony Fletcher and Mark Breitenberg, early modern Englishmen became increasingly concerned with the ambiguities of their masculine performances - what Breitenberg termed "anxious masculinity," an inescapable product of patriarchal societies. ${ }^{24}$

As a typically banal and even pleasurable everyday social practice, the act of gossiping and spreading rumors creates a safe discursive space to work out social anxieties - that is, assuming that the symbolism of these communicative rituals is not misinterpreted by the participants. However, since gossip and, especially, rumor depend on a delicate balance between privacy and sociability, actor and audience, knowledge and assumption, and form and ambiguity, breakdowns can occur during moments of liminal tension, leading to potentially violent confrontations. ${ }^{25}$ These moments of semiotic disjuncture can become instances of significant social or political importance, such as the scandals described by Anna Clark. ${ }^{26}$ The riot of 30 January 1734/5 and Wilkes's exposure of the Medmenham Monks in 1763 are two such examples.

Early modern gossip and rumor present numerous problems in analyzing sources. Gossip and rumor are, by their nature, ephemeral, and, as such, they are two of the most difficult practices to measure and describe. These modes of communication are often private and personal, relying on assumptions, expectations, and unrecorded calculations. Unlike the ethnographer, the historian lacks direct access to the speech acts associated with gossip and rumor and must rely on the textual and visual record. Nevertheless, one must not assume that the presence of the observer necessarily entails more direct access and understanding, a fact corroborated by numerous works on ethnographic subjectivity and reflexive anthropology. ${ }^{27} \mathrm{~A}$ multiplicity of nonoral texts reveal gossip and rumor. Bernard Capp,

${ }^{23}$ On the ambiguities of this performance, see Goffman, Presentation of the Self, 17-21.

${ }^{24}$ Mark Breitenberg, Anxious Masculinity in Early Modern England (Cambridge, 1996); Fletcher, Gender, Sex, and Subordination.

${ }^{25}$ Victor Turner, The Ritual Process: Structure and Anti-structure (New York, 1969).

${ }^{26}$ See Clark, Scandal. These moments are what Clifford Geertz has described as incongruities "between the cultural framework of meaning and the patterning of social interaction"; see "Ritual and Social Change: A Javanese Example," in The Interpretation of Cultures (New York, 1973), 142-69, 169.

${ }^{27}$ For examples, see James Clifford, The Predicament of Culture: Twentieth-Century Ethnography, Literature, and Art (Cambridge, 1988); James Clifford and George E. Marcus, eds., Writing Culture: The Poetics and Politics of Ethnography (Berkeley, 1986); George E. Marcus and Michael J. Fischer, Anthropology as Cultural Critique: An Experimental Moment in the Human Sciences, 2nd ed. (Chicago, 1999). 
for example, has shown the potential for court documents to reveal the context of early modern gossip. In some instances, historians can discover overt gossip and rumor in letters, as I do in my discussion of the Calves-Head Club. However, descendants have a tendency to destroy the most salacious textual remains, as was the case with John Wilkes's daughter Polly, who burned the most valuable archive about the events, gossip, and rumor about "St. Francis's monks" and the events of $1763 .^{28}$

Alternatively, important evidence for gossip and rumor can be found in eighteenth-century print culture. Symbols, allusions, and tropes were part of a complex discursive world in which author, printer, and reader collaboratively created meaning, and the assumptions made by authors and printers in the eighteenth century often point to the "common knowledge" of a document's readership. ${ }^{29}$ As demonstrated in the work of Hannah Barker and Bob Harris, despite the bribing/ patronage of editors and authors by politicians, the print world of midcentury London catered to a market of savvy consumers who wielded influence over the content of print productions. ${ }^{30}$ Thus, historians can read the world of print for popular knowledge-left overtly in gossip columns or subversively through innuendo, assumptions, or symbols. The world of print was an important territory for the fashioning, reproduction, and transformation of gossip and rumor.

"THE SAME IN FORTY-EIGHT AND THIRTY-FOUR": RUMOR, GOSSIP, AND AN EIGHTEENTH-CENTURY RIOT

In the urban rumor mills of the late seventeenth and early eighteenth centuries, any street action taking place on the anniversary of Charles I's execution, 30 January, would have been charged with political and religious overtones. The date 30 January 1734/5 was no different, and one writer, referring to the riot, claimed that it was "the same in forty-eight and thirty-four." 31 The memory of the Civil War in England remained fresh in the minds of Londoners, and stories continuously circulated about a network of radical republican, Low Church revolutionaries that met every 30 January to celebrate the fate of the Stuart monarch. These groups, called Calves-Head Clubs, were ubiquitous specters of revolution - an urban myth used to paint religious or political opponents as antimonarch and antichurch. Stories-certainly fictional-about secret meetings of Calves-Head Clubs were also popular among the reading public, helping to sell newspapers and pamphlets. The earliest accounts of Calves-Head Clubs claimed that they celebrated a "Feast, and rejoice, in Memory of the most Barbarous Murder that the Sun ever saw: or Man

\footnotetext{
${ }^{28}$ John Almon, The Correspondence of the Late John Wilkes (London, 1805), 1:vii.

${ }^{29}$ See, e.g., John Brewer, "The Number 45: A Wilkite Political Symbol," in England's Rise to Greatness, 1660-1763, ed. Stephen B. Baxter (Berkeley, 1983), 349-80.

${ }^{30}$ Hannah Barker, Newspapers, Politics and English Society, 1695-1855 (London, 2000), and Bob Harris, A Patriot Press: National Politics and the London Press in the 1740s (Oxford, 1993). Compare Jeremy Black, The English Press in the Eighteenth Century (London, 1987).

31 "An Epigram on the Calves-head Club Jan. 30, 1734," Grub-Street Journal, no. 271 (6 March 1734/5): 1r-2v. Interestingly, the poem published in 1734/5 was reprinted in London at the height of the Terror in 1794 in The Poetical Farrago: Being a Miscellaneous Assemblage of Epigrams and other Jeux d'Esprit, vol. 2 (London, 1794), 17.
} 
or Devils were capable of committing." ${ }^{32}$ One 1691/2 satire depicted a lecturer proclaiming on 30 January: "When a Man Loaths Monarchy, and Longs for a Commonwealth, that we may Govern Higgledy Piggledy all over our own Heads: this is that which I recommend to you. Brethren, this Calves-Head Feast, as the World calls it, is held amongst us, The Chosen of Israel. For a Memorandum, and to Congratulate each other for that Blessed Action in Lopping off the Head of Charles I." ${ }^{33}$ A pamphlet from Queen Anne's reign reads:

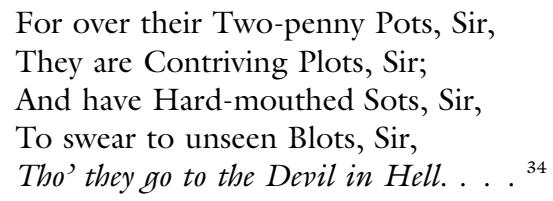

By 1734/5, rumors of Calves-Head Clubs had circulated for decades, especially in periods of religious and political strife. In particular, the image of the CalvesHead Clubs was shaped and reshaped during the first years of the eighteenth century, and it is in writings from this period that the rumored Calves-Head rituals are first described in great detail. Jonathan Swift described the rituals as follows:

The Meat shall represent the TYRANT's Head, The Wine, his Blood, our Predecessors shed: Whilst an alluding Hymn some Artist sings, We toast Confusion to the Race of Kings. ${ }^{35}$

More than likely, Swift drew his analysis of the Calves-Head proceedings from the extremely popular Secret History of the Calves-Head Club by Ned Ward first published in 1702. Ward claimed that the men of the Calves-Head Clubs celebrated the death of Charles I with an "Anniversary Anthem . . . and a Calves-Scull fill'd with Wine or other liquor." 36 Thomas Brown's satirical Letters from the Dead to the Living described members of the Calves-Head Club celebrating 30 January with Ludlow the regicide. ${ }^{37}$ Supposedly, an axe hung in their clubroom to celebrate both the weapon of execution and the executioner of Charles I.

If on that night in 1734/5 the young men had in fact thrown a calf's head into the fire, as reported in the Gentleman's Magazine, the mob would certainly have associated them with the rumored Calves-Head Club. And, surely, the crowd would have known about these men's radical sympathies if, as one Grub Street writer claimed, they had made the following toasts:

${ }^{32}$ Reflections upon Mr. Stephen's Sermon Preach'd before the Honourable House of Commons at St. Margaret's Church in Westminster, 30 January 1699/700 (London, 1700), 11.

${ }^{33}$ Daniel Bergice, A Lecture Held Forth at the Calves-Head Feast before a Society of Olivarians and o Round-Heads (London, 1692), 4.

${ }^{34}$ The Loyal Calves-Head Club: or, Commonwealths-Men, Who Meet Every Night at the Sign of the Tatler, Newgate-Street; To Settle Affairs of Church and State, Just as before in Forty Eight (n.p., n.d.).

${ }^{35}$ [Jonathan Swift], T-l-nd's Invitation to DISMAL, to Dine with the Calves-Head Club (London, 1712).

${ }^{36}$ [Ned Ward], The Secret History of the Calves-Head Club: or, the Republican Unmasqu'd, 2nd ed. (London, 1703), 10.

${ }^{37}$ Edmund Ludlow sat as a judge at Charles I's trial and signed the death warrant. Thomas Brown, A Continuation or Second Part of the Letters from the Dead to the Living (London, 1703), 234-44. 
To the pious Memory of Oliver Cromwell

Damnation to the Race of the Stuarts

To the glorious Year, 1648 .

To the Man in the Mask, \&c. \&c. \&c. ${ }^{38}$

But, the evidence from 30 January 1734/5 suggests that it was not Calves-Head symbolism that provoked the crowd. Interestingly, some of the "healths" the anonymous writer quoted occurred in earlier, satirical Calves-Head literature. ${ }^{39} \mathrm{It}$ is probable that the Grub Street press grafted the entire Calves-Head theme onto what may simply have been an incident of eighteenth-century street violence. The gentlemen in the tavern could have been innocent of participating in the rituals of the Calves-Head Club. William Hogarth was probably one of the first satirists to respond to the 30 January riot. A drawing ascribed to him and titled The True Effigies of the Members of the Calve's Head Club, Held on ye 30th of January 1734. at ye Golden Eagle in Suffolk Street in ye County of Middlesex is one of several examples that draws from earlier literary and visual descriptions of Calves-Head Clubs (figs. 2 and 3). ${ }^{40}$ This drawing is an example of one of Hogarth's impolite "conversation pieces." ${ }^{41} \mathrm{He}$ drew this image in the reverse for a print engraved by Gerard Vandergucht, intentionally referencing a Calves-Head image first published in 1707 in the sixth edition of Ned Ward's Secret History of the Calves' Head Club. ${ }^{42}$ Both Hogarth's and Ward's images include a calf's head and an axe. However, in Hogarth's drawing, the "puritans" have been replaced by libertines, and instead of Satan and the gorgon, an image of Charles I's execution hangs over their heads. ${ }^{43}$ Hogarth's direct allusion to the image in Ned Ward's book reveals how popular Ward's account remained in the 1730s. In this image, the libertine replaces the puritan as the symbol of political disorder, a trope that had been articulated since Charles II's restoration. ${ }^{44}$ Furthermore, it shows that the symbols

${ }^{38}$ The True Effigies of the Members of the Calve's Head Club (London, 1734/5).

${ }^{39}$ For example, see Brown, Letters from the Dead to the Living; Peter Browne, A Discourse of Drinking Healths (Dublin, 1716), 161; Joseph Trapp, The Character and Principles of the Present Set of Whigs, 2nd ed. (London, 1711), 22, 42.

${ }^{40}$ Both A. P. Oppé (The Drawings of William Hogarth [New York, 1948], 35-36) and Ronald Paulson (Hogarth's Graphic Works, 3rd ed. [London, 1989], 35) are doubtful of John Ireland's attribution of the original drawing to William Hogarth (Windsor Castle Print Room). Stylistically, the drawing is questionable. However, the subject matter and "impolite" conversation piece setting is Hogarthian.

${ }^{41}$ See David Solkin, Painting for Money: The Visual Arts and the Public Sphere in Eighteenth-Century England (New Haven, CT, 1992), 78-105.

${ }_{42}$ There is a second version of this print, sold by George Foster at the White Horse in St. Paul's Church Yard, which included a poem. This poem was also printed in The Bee, or Universal Weekly Pamphlet 9, no. 106, January 1734/5, 39.

${ }^{43}$ Nevertheless, the association with Satan did not disappear in $1734 / 5$, as exemplified by a poem reading: "To pious CHARLES, and regal state, / These sons of Hell, to shew their hate; / The Martyr's blood now represent / By wine- the DEVIL's sacrament" in Grub-Street Journal, no. 270 (27 February, 1734/5): $2 \mathrm{r}$.

${ }^{44}$ The literature on libertinage in later Stuart England is much more developed than that of the mideighteenth century. See Anna Bryson, From Courtesy to Civility: Changing Codes of Conduct in Early Modern England (Oxford, 1998); P. M. Cryle and Lisa O'Connell, eds., Libertine Enlightenment: Sex, Liberty, and License in the Eighteenth Century (New York, 2004); Melissa M. Mowry, The Bawdy Politic in Stuart England, 1660-1714: Political Pornography and Prostitution (Hampshire, 2004); Randolph Trumbach, "Erotic Fantasy and Male Libertinism in Enlightenment England," in The Invention of Pornography: Obscenity and the Origins of Modernity, 1500-1800, ed. Lynn Avery Hunt (New York, 


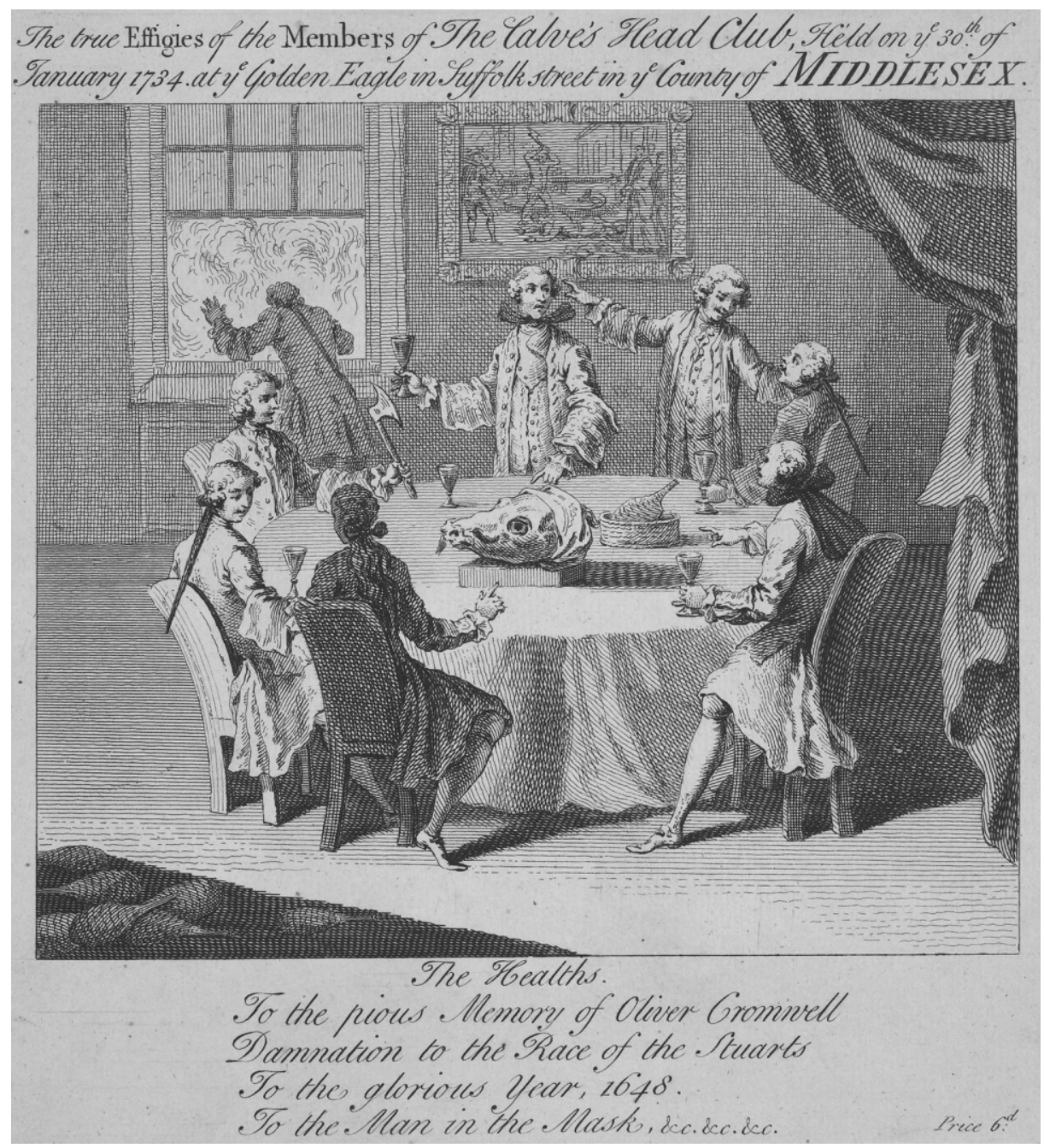

Figure 2-Attributed to William Hogarth, The True Effigies of the Members of the Calve's Head Club, Held on ye 30th of January 1734. at ye Golden Eagle in Suffolk Street in ye County of Middlesex [interior], 1735. (C) by the Trustees of the British Museum.

that figured in the earlier Calves-Head literature remained important reference points for readers in the 1730s. In fact, Hogarth's drawing, which did not include any supplementary information about Calves-Head clubs, suggests a popular literacy—both visual and textual-about their rumored subversive meetings.

1993), 253-82, and Sex and the Gender Revolution; James Turner, Libertines and Radicals in Early Modern London: Sexuality, Politics, and Literary Culture, 1630-1685 (Cambridge, 2002); Rachel Weil, "Sometimes a Scepter Is Only a Scepter: Pornography and Politics in Restoration England," in Hunt, Invention of Pornography, 125-53. Bryson, Mowry, and Turner aptly demonstrate that libertinism, both in rhetoric and practice, served to bolster both masculine and elite privilege. However, there were dangers inherent to the libertine lifestyle, which could lead to popular critique and even crowd action. This point is exemplified no better than in the Bawdy House Riots of 1668. 


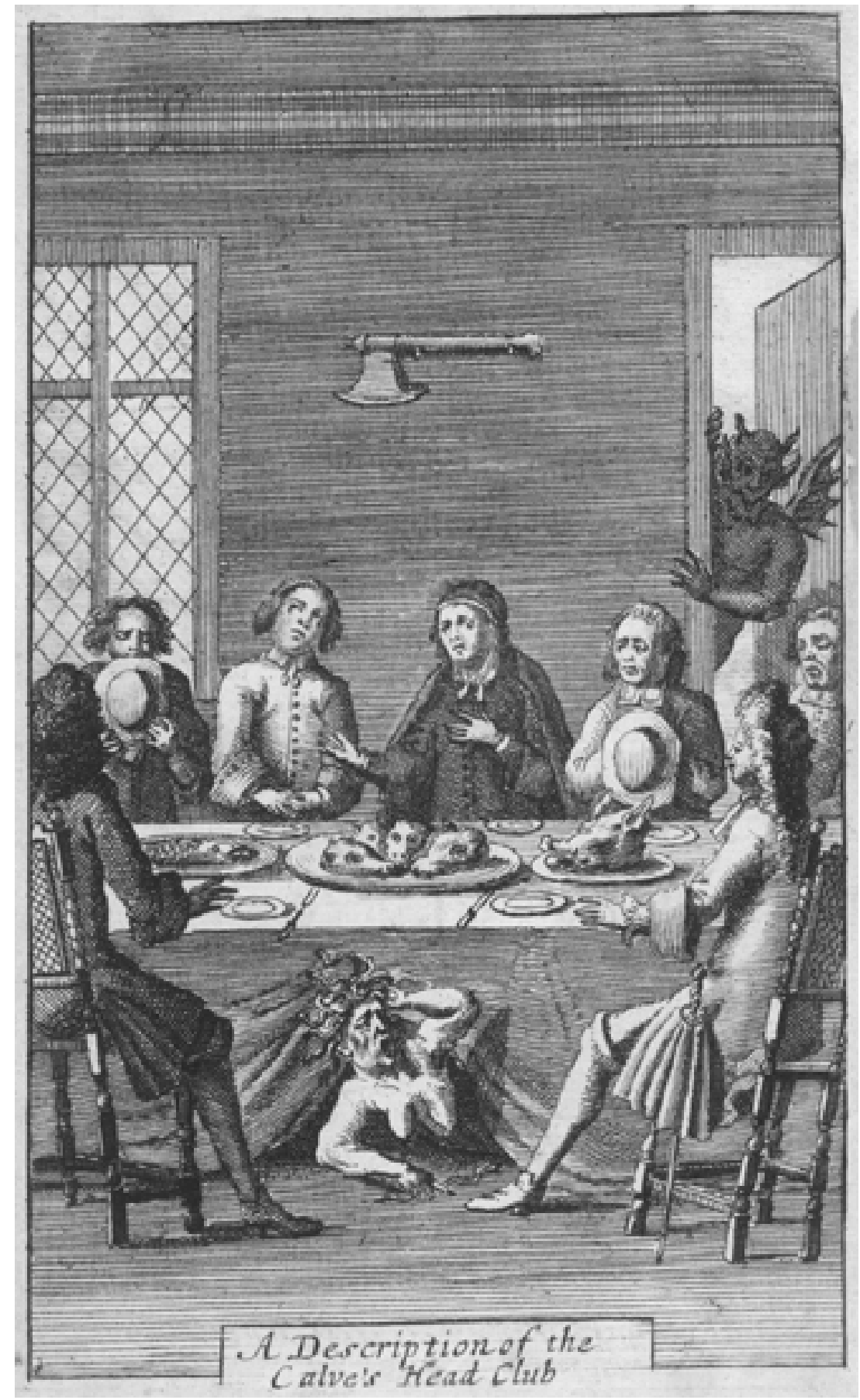

Figure 3-A Description of the Calve's Head Club, in Ned Ward, Secret History of the Calve's Head Club, 6th ed. (London, 1707), opposite title page. Reproduced with the permission of the Huntington Library, San Marino, CA. 
A second image (fig. 4) from the 30 January 1734/5 event provides another visual perspective on the Calves-Head episode. This print, called The True Effigies of the Members of the Calves Head Club, held on the 30th of January 1734, in Suffolk Street in the County of Middlesex, showed the exterior of the Golden Eagle Tavern at approximately 7:00 p.m., immediately before violence broke out. In the background, the gentlemen appear in the window of the tavern with the characteristic paraphernalia of the Calves-Head Clubs, while a crowd in the foreground gathers around a bonfire. In the Golden Eagle's first window, the men drink wine to make a toast to the execution of Charles I. In the second window, two men hold up a calf's head, and in the third window a masked "executioner" wields an axe. The crowd contrasts the men in the window by being composed mostly of middling gentlemen, although there are a few beggars and prostitutes observing the dialogue. Accompanying the image are the toasts mentioned above, along with a short poem:

New Regicides bad as the old dare call

The Martyrs blood on their own Heads to fall

And black as those who' Frocks \& Vizors wore

These Sons of Hell thus trample on his Gore.

Like Hogarth's image, this print borrowed from and referred to well-established popular beliefs about the rituals of Calves-Head Clubs. They followed a preexisting narrative, onto which the particulars of the $1734 / 5$ event were grafted, whose particulars were likely culled from rumors and gossip that began to circulate after the violence took place. In all, no less than eight separate references to the event can be found in the Grub-Street Journal, The Gentleman's Magazine, The London Magazine, Read's Weekly Journal, and The Bee as well as in five 6d. prints. ${ }^{45}$ Keeping in mind the popularity of these newspapers and magazines, the increased population of London during the season, and the circulation of periodicals in the coffeehouses and clubs, we can estimate approximately 1,000-5,000 readers per edition, and possibly more for The Gentleman's Magazine. Assuming print runs of 500, contemporary estimates of twenty to fifty readers per purchased print, and an untold number of readers who saw them in print shop windows, each of the five Calves-Head prints could easily have been seen by ten thousand people. ${ }^{46} \mathrm{In}$ short, much of London would have read or heard about the events of 30 January.

Yet, this should not suggest that the Calves-Head story was completely fabricated by the press. After all, the men in the tavern were quite aware of the symbolic

\footnotetext{
${ }^{45}$ For a complete list of prints, see Frederick George Stephens, Catalogue of Political and Personal Satives Preserved in the Department of Prints and Drawings in the British Museum (London, 1978), 86-90. See also Grub-Street Journal, no. 266 (30 January 1734/5): 3, and Read's Weekly Journal: or, British Gazetteer, 8 February 1735, 3.

${ }^{46}$ Print runs and readership numbers are difficult to ascertain. The above numbers rely on Brewer, Party Ideology and Popular Politics, 39-160. See also Arthur Aspinall, Politics and the Press, 1780-1850 (London, 1949), and "Statistical Accounts of the London Newspapers in the Eighteenth Century," English Historical Review 63, no. 247 (1948): 201-32; Hannah Barker, Newspapers, Politics and English Society; Jeremy Black, English Press; Robert Louis Haig, The Gazetteer 1735-1797: A Study in the Eighteenth-Century Newspaper (Carbondale, IL, 1960); Paul Kaufman, Libraries and Their Users: Collected Papers in Library History (London, 1969); Tessa Watt, Cheap Print and Popular Piety, 1550-1640 (Cambridge, 1991).
} 


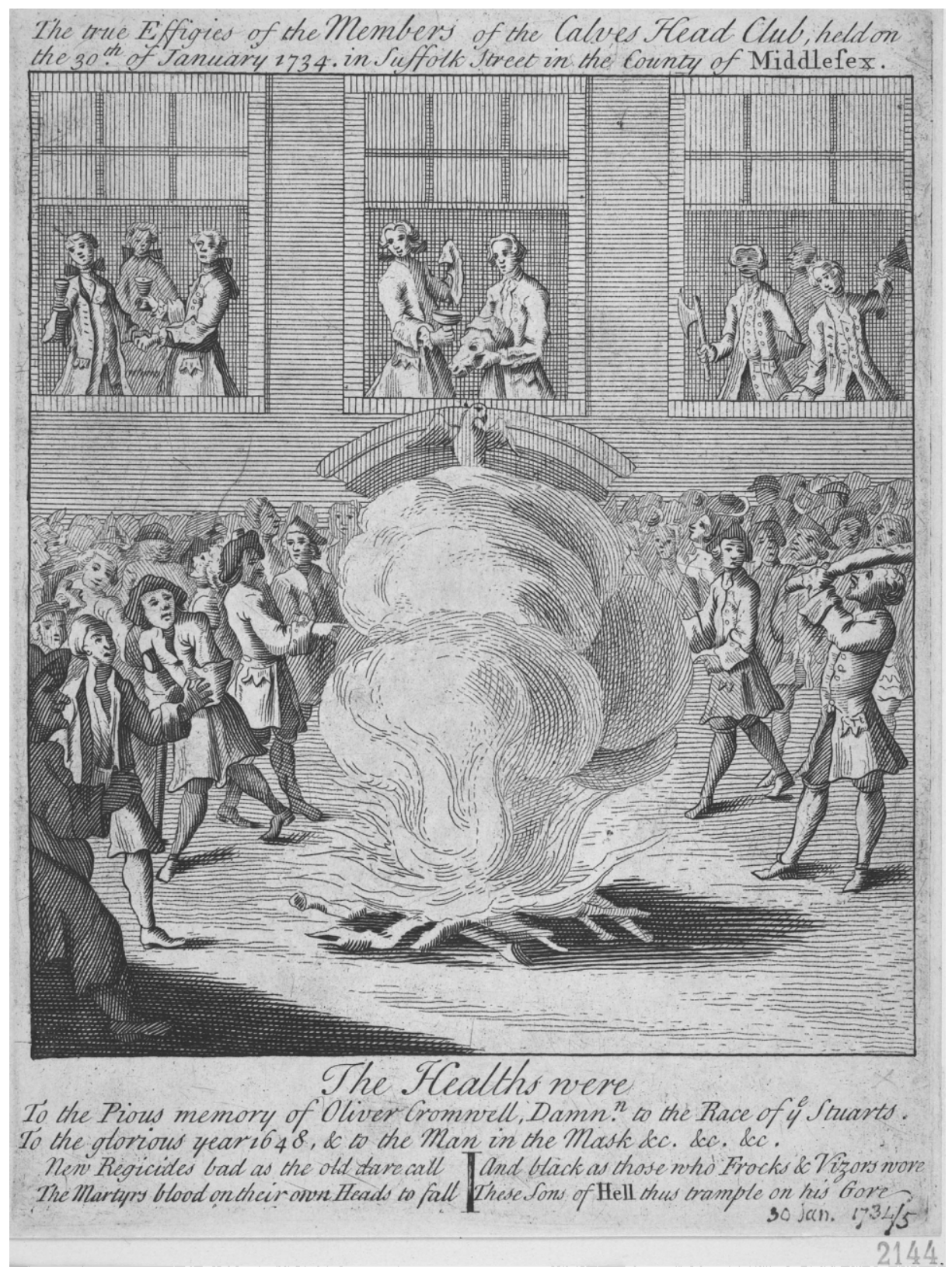

Figure 4-The True Effigies of the Members of the Calve's Head Club, beld on the 30th of January 1734, in Suffolk Street in the County of Middlesex [exterior], 1735. () by the Trustees of the British Museum. 
significance of the date. They understood the nature of street theater, and they knew that a bonfire would invite a crowd. Moreover, it was well known that William Denny hated the Stuarts, and it is possible that his presence stirred rumors of radical republicanism. ${ }^{47}$ And while we will never know their intentions, we can be certain that the gentlemen and the crowd participated in some sort of ritual act together-a performance that quickly got out of control. While playing their respective roles, the mob and the gentlemen inhabited separate ritual spheres. The former was in the street. The latter was in the Golden Eagle, separated by the physical barrier of the tavern exterior as well as their height over the square. The gentlemen drank claret, the drink of the French, while the crowd drank beer, the drink of John Bull. The men in the tavern dressed in the fashions of the continental fop, while the men in the street dressed in the more modest attire of London. Despite sharing in the performance, there was a physical, symbolic, and social division among the participants. Yet these divisions were blurred in the haze of alcoholic revelry and the symbolic tensions of 30 January. The men within the tavern attempted to inhabit the borderland between the private club and the street, between elite and popular culture, between jesting libertine and boorish hellion. They failed, however, in negotiating the less ambiguous language of politics, and it was this that turned a drunken revel into a violent encounter.

It is unclear what angered the crowd on 30 January $1734 / 5$, but it was probably not a toast to Cromwell. More probable was the gentlemen's endorsement of Robert Walpole's recently reelected ministry, which had increasingly lost popular support because of Walpole's excise schemes. ${ }^{48}$ It is unlikely that the gentlemen in the Golden Eagle threw a calf's head into the fire. The men, after all, were neither republicans nor puritans and would have perceived this as an obvious mistake. The men's blunder came when they initiated a political discourse with the crowd. In all other aspects of this street theater, they kept themselves somewhat separate from the mob. In this one arena, they attempted to engage with the crowd. Whether one believes Grub Street's contention that the men toasted Cromwell or the gentlemen's argument that "the only healths they drank to the populace were Royal Family, Liberty \& Property, \& the present Administration, which last not happening to be very popular was the only cause of the Riot," the consensus was that the frolic ended with political toasting, the men having engaged in what Greg Dening has termed "bad language," a failure to properly understand the ambiguities of their performances. ${ }^{49}$ Even Middlesex alluded to their confusion over what to do after they realized the consequences of starting a bonfire on 30 January. He later claimed that they decided to deflate the situation by proposing

\footnotetext{
${ }^{47}$ John Ingamells (A Dictionary of British and Irish Travellers in Italy, 1701-1800 [New Haven, CT, 1997], 292) quotes Lord Essex about Denny (State Papers Foreign, The National Archives [TNA]: Public Record Office [PRO] 92/37), "He is able to give some Lights as to the Pretender and the several Factions and Dispositions of the people about him; and I dare say, if it be so, besides the Satisfaction he will find in doing thereby his Duty as a faithfull Subject to the King, He will not be a little prompted to it, by the ill usage he has met with from that whole party during his confinement at Rome, which has raised in him a strong resentment against them."

${ }^{48}$ Nicholas Rogers, Whigs and Cities: Popular Politics in the Age of Walpole and Pitt (Oxford, 1989), esp. 46-59; Raymond Turner, "The Excise Scheme of 1733," English Historical Review 42, no. 165 (1927): 34-57.

${ }^{49}$ Smyth to Spence, 5 February 1734/5. Greg Dening, Mr. Bligh's Bad Language: Passion, Power and Theatre on the Bounty (Cambridge, 1992).
} 
"Loyall and popular Healths to the Mob out the window." ${ }^{50}$ This breech of social etiquette politicized the situation. In other words, what made their language bad was its political content, which engaged with a crowd already charged with the energy of the atmosphere of 30 January. ${ }^{51}$ It was this language that catalyzed preexisting gossip and rumor networks, with their common knowledge expectations about Calves-Head Clubs.

Gossip and rumor worked quickly in eighteenth-century England. On 31 January, the press had already begun rehashing the story. Within days, rumors about the event were circulating in the provinces. By 5 February, Joseph Spence at Oxford was asking his fellow Society of Dilettanti member Arthur Smyth what had actually happened. On the same day, Smyth wrote an account for Spence titled "Account of a Riot in London, occasioned by a drunken frolic of Lord Middlesex and some friends." He wrote to Spence because "the affair has been grossly misrepresented all over Town \& in most of the publick papers; and if ever you hear it mention'd in Company, in justice to the gentlemen's characters I hope you will vindicate 'em." "52 In effect, Smyth and Spence were gossiping to counter the spread of rumors in both the press and in their social networks.

Even in this first letter, one can see how the story began to change. For example, Smyth's account claimed that the gentlemen in the Golden Eagle were not the only people having a bonfire on Suffolk Street that day. Smyth ended the letter by promising to "tell you the other particulars when I see you in Town." On the next day, fearing that Spence had not received his earlier letter, Smyth wrote a second letter in which he went into more detail. In it, Smyth fretted about the reputation of his friends. He also added to his original description. Interestingly, in the day that had passed, Smyth's story changed. In this new version, the men were no longer drinking claret but rather champagne-still a French drink but no longer a red wine that could serve as a symbol of the king's blood. This time, the mob and the tavern goers did not initially interact. The first contact between the men and the mob occurred when "some gentlemen animat[ed] 'em [the mob] \& g[ave] 'em money to insult the gentlemen in the Tavern." It was only at this point that Middlesex and the others bought the crowd beer, hoping to prevent an altercation. When they toasted the political administration, "this rais'd a few feint claps but a general hiss; some of the company were sober enough to know that the anger of the mob wou'd not end there, \& so they immediatly shut down their windows, wch was no sooner done but the mob furiously attack'd the house with stones \& brickbats, broke all the windows to pieces \& woud have probably have broke open the house if the Guards from St. James's had not come to the relief of the gentlemen." At the end of his letter, Smyth added, "The King . . . looks upon it as every other person of sense does as a drunken frolick." ${ }^{53}$

If George II, as Smyth suggests, looked on the event as a "drunken frolick," then it is telling that Smyth felt compelled to exert so much energy to control the gossip among his friends and social equals. This seems the type of action that any aristocratic youth of the period could have participated in without repercus-

\footnotetext{
${ }^{50}$ Middlesex to Spence, 9 February 1734/5.

${ }^{51}$ In fact, there was another bonfire down the street.

${ }^{52}$ Smyth to Spence, 5 February 1734/5.

${ }^{53}$ Smyth to Spence, 7 February 1734/5.
} 
sions. In fact, this is exactly the behavior one would expect of privileged youths trained to believe, as Anna Bryson has claimed, that "gentlemanly status [invested] rank with freedom from constraint"-that nobility nourished transgressive social practices. ${ }^{54}$ The account of Middlesex, one of the participants, provides some reasons for Smyth's concern.

Middlesex, like Smyth, felt obligated to explain the events of 30 January to Joseph Spence. His letters reveal the confidence and precociousness of a twentysomething noble of the eighteenth century. Middlesex addressed his good friend Spence as "Spanco," a nickname that he had no doubt picked up while the men toured through Europe together in the preceding years. ${ }^{55} \mathrm{He}$ encouraged his friend to "defend your Friends (as I don't in the least doubt you have inclination to do)." Still, his text spilled over with the "wink-wink, nudge-nudge" of gentlemanly libertinism-defend our honor in public, but let us laugh about it together in the back room. In his story, he became a hero, dodging "stones as well as [his] drunk friends who were now brandishing swords inside desiring to go out and disperse the mob." If Smyth's story embellished the plot by saying that some gentlemen in the crowd stirred the mob to violence, Middlesex took it one step further. He wrote, "The person who first stir'd up the Mob is known, he first gave 'em mony and then harangu'd them in a most violent manner. I don't know if he did not fling the first stone himself. He is an Irish man and a Priest, belonging to Imberti the Venetian Envoy." Middlesex had embroidered his narrative by blaming those great bugbears of English civility, the Irish and the Catholics.

This microhistory of the Golden Eagle riot reveals several important aspects of eighteenth-century London society. From a purely functionalist perspective, one can see the role that gossip and rumor played in the formation and reproduction of social boundaries. At its most basic, Grub Street, while attempting to sell newspapers, was monitoring public morality-certainly differently than Addison and Steele, but no less effectively. In the Grub Street narrative, a social conflict had taken place between the tempered, commonsense morality of average Londoners and the excesses of the English nobility. A poem in The Bee approached the point directly:

Strange Times! When noble peers, secure from riot, Can't keep Noll's [Cromwell's] annual festival quiet. ${ }^{56}$

This poem implied that Londoners expected and even tolerated excess among the nobility, but when this excess violated proper etiquette-not necessarily "polite" etiquette- then there existed the possibility of social and political outrage and even violence. Once the initial breach of decorum occurred, the moral economy of popular gossip and rumor took over. Street gossip helped encourage Grub Street by providing ready-made networks for rumors' distribution. Grub Street relied on knowledge stored in popular oral traditions and could assume a certain

\footnotetext{
${ }^{54}$ Anna Bryson, From Courtesy to Civility, 269. Anna Clark ("The Chevalier d'Eon and Wilkes: Masculinity and Politics in the Eighteenth Century," Eighteenth-Century Studies 32, no. 1 [1998]: 19-48) has argued that this ideal increasingly disappeared after the 1770s.

${ }^{55}$ Middlesex to Spence, 9 February 1734/5.

${ }^{56}$ [Eustace Budgell], "Verses Occasioned by the Calves-Head Club, Jan. 30, 1734-5," in The Bee, or Universal Weekly Pamphlet 9, no. 106 (January 1734/5): 39.
} 
amount of literacy about the Calves-Head Club. Unlike earlier Calves-Head publications, however, Grub Street could only expect a limited reaction to threats to the government and church. On the one hand, the new Walpole ministry had recently formed in late 1734 and was fairly unpopular with most citizens. On the other hand, while the threat of republicanism-or Jacobitism for that matterhad not disappeared, most Londoners in late 1734 felt little threat to the church or state. For these reasons, it is not surprising that the publications of February $1734 / 5$ were just as concerned with defining social difference as they were with linking the gentlemen to Calves-Head activities. In particular, the press alluded to popular concerns over gender and class.

Grub Street portrayed the gentlemen as aristocratic fops, overly concerned with fashionable fripperies. Hogarth's drawing reveals men in fastidiously curled wigs sporting decorative ribbons and garters, which they later hid in "cole-holes" when "[f]orc'd to run down to vaults for safer quarters." ${ }^{57}$ Hogarth's overtly phallic rendering of their wigs was a reminder that for all their primping, they could only mimic masculine qualities. ${ }^{58}$ The frills on their shirts reminded the readers of continental fashions, a none-too-oblique reference to the men's recently completed Grand Tours. To underline the popular conception that these men had been corrupted by continental influences, the second print showed one of the members in a mask, but not the mask of an executioner. Rather, it was the costume veil of the carnival masquerade. In all, these delicate-looking men with their feminized foppishness contrasted with the powerful physique of the street crowd. ${ }^{59}$ Unlike the portrayal of the mob, the gentlemen in the tavern were not wholly English, not wholly masculine, and certainly not the popular image of John Bull.

If Grub Street reflected popular gossip and rumors that critiqued these men for a fetishization of continental fashion and manners bordering on the feminine, the gossip among Smyth, Spence, and Middlesex presented a different set of masculine ideals. Despite an attempt to rein in the more extreme rumors- that is, that they were members of a Calves-Head Club-these men used gossip to portray themselves as the ideal figures of aristocratic youth. From the drinks they consumed to the oaths they declared, Middlesex and Smyth figured their friends as distinct from the common rabble. Certainly, they were engaged in unrestrained indulgence, but libertinism was their right. For these men, the 30 January incident became, through internal gossip, a way to pleasurably relive their former mischief together. Among their social equals, their profligate consumption of alcohol and the ensuing violence was merely a "frolick," even in the mind of the king. The violent brandishing of their swords was acceptable conduct-masculine conduct-among an aristocratic male youth culture taught to idealize codes of honor. Gossiping together and among their peers about 30 January strengthened their friendly bonds and idealized their behavior rather than undermining their reputations.

\footnotetext{
${ }^{57}$ Ibid.

${ }^{58}$ This was not the last time that Hogarth would use wigs to humiliate members of the Dilettanti. See his print The Five Orders of Perriwigs as They were Worn at the Late Coronation Measured Architectonically (London, 15 October 1761).

${ }^{59}$ On the fop, see Philip Carter, "Men about Town: Representations of Foppery and Masculinity in Early Eighteenth Century Urban Society," in Barker and Chalus, Gender in Eighteenth-Century England, $31-57$.
} 


\section{"I SINNED ONLY FROM VANITY OF BEING IN THE FASHION!": THE MONKS OF MEDMENHAM ABBEY}

By 1763, the members of the Calves-Head Club were no longer the youth of 1734/5. Joseph Spence was an Oxford don and the internationally renowned author of Polymetis. Arthur Smyth was the archbishop of Dublin. Middlesex was a central member of the Society of Dilettanti, which had become a much more formal and influential institution. In fact, under the leadership of Middlesex, Francis Dashwood, Baron le Despencer (1708-81), John Montagu, Earl of Sandwich (1718-92), James Gray, and others, the group had become prominent in cultural affairs in its efforts to promote Italian opera in London and to help establish the Royal Academy. ${ }^{60}$ The society had even subsidized the majority of James Stuart and Nicholas Revett's expedition to Greece and their subsequent publication of Antiquities of Athens (1762).

Yet despite the intellectual seriousness of the Dilettanti, Middlesex still had a habit of surrounding himself with the most notorious rakes of his age, parts that the younger Dashwood and Sandwich played perfectly. However, to the other members of the Dilettanti, the young men's actions could prove a liability. Their reputation was problematic to the Dilettanti, who were attempting to establish cultural and scientific credentials in the Enlightenment public sphere. In an age in which "public utility" and "service to the public good" were supposed to be the modus operandi of respectable societies, an entire group's reputation could be compromised should gossip or rumor associate it with ribald excess. ${ }^{61}$ For example, Horace Walpole's 1743 letter to Horace Mann reflected the sentiments of many aristocrats, gentry, and middling sorts about the Dilettanti and exemplifies the close links between the private affairs of individuals and the reputation of an entire group: "There is a new subscription formed for an Opera next year, to be carried on by the Dilettanti, a club, for which the nominal qualification is having been in Italy, and the real one being drunk; the two chiefs are Lord Middlesex and Sir Francis Dashwood, who were seldom sober the whole time they were in Italy." ${ }^{62}$ In this context, libertine freedom increasingly became modified because,

\footnotetext{
${ }^{60}$ On the Dilettanti's association with the establishment of a Royal Academy, see Francis Milner Newton to Society of Dilettanti, 31 January 1755, Society of Antiquaries, Society of Dilettanti Letter Book (SDLB), fols. 122-29, and Society of Antiquaries, Society of Dilettanti: Society Minutes (SDSM), 6 March 1774.

${ }^{61}$ On the importance of association and the "public good," see Jan Golinski, Science as Public Culture: Chemistry and Enlightenment in Britain, 1760-1820 (Cambridge, 1992); Larry Stewart, The Rise of Public Science: Rhetoric, Technology, and Natural Philosophy in Newtonian Britain, 1660-1750 (Cambridge, 1992).

${ }^{62}$ Walpole to Horace Mann, 14 April 1743, in Horace Walpole's Miscellaneous Correspondence, vol. 18, ed. W. S. Lewis (New Haven, CT, 1980), 211. Despite Walpole's disgust at the Dilettanti, he still subscribed to the opera. See William Fauquier to George Gray, 7 March 1743, SDLB, fol. 37. Opera was Middlesex's passion, and he used the Society of Dilettanti's love for things Italian to encourage all members to subscribe to the 1743 season, a cost of $£ 20$ paid up front. Not all members were as enthusiastic as Middlesex. See, e.g., William Denny to Gray, 25 March 1743, SDLB, fol. 33, and Lewis Watson, second earl of Rockingham to Gray, 27 March 1743, SDLB, fol. 51. On Middlesex's opera schemes, see Carole Taylor, "From Losses to Lawsuit: Patronage of the Italian Opera in London by Lord Middlesex, 1739-45," Music and Letters 68, no. 1 (1987): 1-25. There is evidence that the group may have considered an alternative direction. The opera scheme to which Walpole alluded gave Margaret Cecil, Lady Brown a completely different impression of the group. In fact, her relationship
} 
by the mid-eighteenth century, associational life had become a significant form of gentlemanly social status - one that challenged libertinism as a mark of distinction. Therefore, inherent to the associational world of the eighteenth century was the tension between the masculine libertinism of aristocratic individuals and the "polite sociability" of their publicly recognized communities. ${ }^{63}$

Nevertheless, societies and clubs could provide an arena for the pleasures of masculine libertinism. ${ }^{64}$ Even at midcentury, rumors and gossip could have free play among the populace as long as the gentlemanly classes did not acknowledge the truth or falsehood of such information. One of the most extreme examples of this relationship can be found in the histories of the Dilettanti Society and Dashwood's "Monks of the Order of St. Francis." Individual members of the Dilettanti walked the line between civil and uncivil behavior both in their private lives and by their association with groups such as Francis Dashwood's Medmenham Monks, which included Dashwood, Sandwich, Churchill, Thomas Potter, Paul Whitehead, and George Bubb Dodington, among others. ${ }^{65}$ The monks enjoyed residence at Dashwood's estate, a leisurely day's ride from London, for up to a week. In the London public sphere, gossip and rumor about Medmenham became gossip and rumor about the Dilettanti. In 1763, this connection would have very

with the Dilettanti members and their plans to support the Italian opera in London was so positive that at least one member of the Society, William Fauquier, flirted with the idea of proposing her for membership. He wrote to the secretary of the Society in 1743 , "I think $L^{y}$ Brown is such a well wisher to the Society that she might to be chose a Member, excus'd of the Forfeits [monetary penalties for missing group meetings] for not attendance"; Fauquier to Gray, 7 March 1743, SDLB, fol. 37. Nothing became of his proposition, probably because the men considered their meetings off-limits to an aristocratic woman. Coffeehouses and taverns could be spaces of violence or drunkenness, hardly the territory of women who did not wish to be associated with prostitution or poverty. This, in fact, was implied by Fauquier's assumption that she could not attend the meetings and thus needed to be "excus'd of the Forfeits."

${ }^{63}$ On the significance of understanding politeness and sociability in the eighteenth-century public sphere, see Helen Berry, "Rethinking Politeness in Eighteenth-Century England: Moll King's Coffee House and the Significance of 'Flash Talk," Transactions of the Royal Historical Society, 6th ser., 11 (2001): 65-81; Carter, Men and the Emergence of Polite Society; Brian Cowan, "What Was Masculine about the Public Sphere? Gender and the Coffeehouse Milieu in Post-Restoration England," History Workshop Journal 51 (2001): 127-57; and Lawrence E. Klein, "Coffeehouse Civility, 1660-1714: An Aspect of Post-Courtly Culture in England," Huntington Library Quarterly 59, no. 1 (1997): 31-51, "Liberty, Manners, and Politeness in Early Eighteenth-Century England," Historical Journal 32, no. 3 (1989): 583-605, and Shaftesbury and the Culture of Politeness: Moral Discourse and Cultural Politics in Early Eighteenth-Century England (Cambridge, 1994).

${ }^{64}$ As will become evident in my discussion below, I disagree with Shearer West, "Libertinism and the Ideology of Male Friendship in the Portraits of the Society of Dilettanti," Eighteenth-Century Life 16, no. 2 (1992): 76-104, on several accounts. I find little evidence to suggest that the Dilettanti were republicans, especially when one considers the membership of the group throughout the century. Certainly the members supported various factions, but at no time did the Dilettanti or its members give any hint of antimonarchical sympathies. While "libertines" may have believed in some form of religious freedom, the archival evidence does not reveal a "theme of atheism" among the Dilettanti as West suggests (86). For example, the fact that Dashwood dressed as a monk does not prove that he was an atheist. In fact, he worked with Benjamin Franklin to revise the Book of Common Prayer (Bodleian MS D.D. Dashwood [Bucks] C.5 B12/2). His garb probably suggests an anti-Catholicism that was typical of the age.

${ }^{65}$ There is no definitive list of members. See, e.g., Ross, "Franklin, Dashwood, and the Mad Monks of Medmenmham," 58. My article discusses only those men for whom there is definitive evidence of membership. 
public repercussions. The consequences of this association would haunt the Dilettanti for the rest of the eighteenth century.

In many ways, the story of 1763 is the story of John Wilkes. Therefore, to understand the significance of Medmenham among the gossiping public, it is best to begin with this MP for Aylesbury. By January 1763, Wilkes had published thirty issues of his North Briton, a journal anonymously produced by him and his poet friend Charles Churchill. Its title was a satirical reference to the progovernment Briton and a ministry dominated by the Scottish Bute. The journal's virulently anti-Scottish and anti-Bute tone sparked angry protest from numerous government ministers. Adding to the offensiveness of the journal was Wilkes's refusal to acknowledge it as his own. Hostility went so deep that Wilkes found himself in a duel with William, Earl Talbot, on 5 October 1762. Wilkes's attacks on the government even found him in conflict with several of his closest friends, most notably Francis Dashwood, the financially challenged Chancellor of the Exchequer.

While Wilkes initially underestimated the government's ultimate reaction to the North Briton, he knew his public - in particular, the London middling sorts for whom he became a champion against governmental tyranny. So, when Wilkes caricatured the Monks of Medmenham by privately sponsoring the printing of Secrets of a Convent in the final weeks of January 1763, he had a firm grasp of the popular response. ${ }^{66} \mathrm{He}$ began writing about the Medmenham Monks during 1763 - even proudly claiming membership-because he understood that once the stories about Medmenham became politicized, the moral economy of rumor and gossip would combine with what Helen Berry has called "a fascination with impolite behaviour." The love of scandalous innuendo would take hold of London audiences' imaginations. ${ }^{67}$ Wilkes's intimate knowledge of his audiences, their common knowledge, and their expectations allowed him to adroitly respond to the government's attacks, which increasingly focused on his morality. Wilkes revealed the complicity of government ministers in his libertine activities by transforming rumors about Medmenham into substantiated gossip. Suggesting that the government stepped over the boundary of civil decorum by using knowledge against him that had been obtained through private friendship, he was able to critique a corrupt government that was unable to recognize the line between private affairs and public office - in this case, a government of hypocritical liars using arbitrary state powers to "peach" him.

While it is impossible to discover exactly what Londoners said about Medmenham on the streets, in coffeehouses, or in clubs during 1763, it is nevertheless possible to trace the lineage of rumors as well as the general extent of the public's "knowledge." The club had been meeting since at least October $1754 .{ }^{68}$ Over the next decade, rumors of the goings-on at the abbey in West Wycombe became known to increasingly larger groups of people as the members, their associates, and even their servants spread stories about their activities. The first groups to learn of Medmenham were, no doubt, fellow nobles.

\footnotetext{
${ }^{66}$ The publisher was Matthew Darly, who later supported Wilkes in his bid for Parliament; see The Battle of the Quills: or, Wilkes Attacked and Defended (London, 1768), 50-51.

${ }^{67}$ Berry, "Rethinking Politeness," 67.

${ }^{68}$ Temple to John Wilkes, 12 October 1754, The Grenville Papers: Being the Correspondence of Richard Grenville Earl Temple, K.G., and the Right Hon: George Grenville, vol. 1, ed. William James Smith (London, 1852), 125-27.
} 
Gossip about Dashwood's penchant for imitating the Catholic clergy was known throughout European aristocratic circles as early as 1740, when he was on his Grand Tour with members of the Dilettanti. A particular incident resonated with aristocratic networks of gossip. While in Rome with William Matthias StaffordHoward, the third earl of Stafford, these "mauvais catholiques" caused a "vrai scandalum magnatum" by holding a mock conclave and impersonating Cardinal Ottoboni. From "ce damné Huguenot" came a "répertoire de chansons libertines contre la papauté."

Dashwood had little fear of gossip and rumor about Medmenham. In fact, he took pleasure in encouraging gossip about his "secret" society, especially through his association with the Society of Dilettanti. In 1742, the Society of Dilettanti passed a rule that all members were required to commission portraits of themselves by George Knapton, the society's official painter. ${ }^{70}$ The group hung Knapton's paintings at their meeting room at the King's Arms Tavern. Most of the portraits portrayed the men dressed in costume, often participating in their favorite Grand Tour activities such as drinking, womanizing, and masquerading. Dashwood's depicted him as "SAN FRANCESCO DE WYCOMBO." Significantly, eighteenth-century meeting rooms were not necessarily private rooms. Rather, tavern goers often had access to a society's rented meeting room. In effect, the Dilettanti's meeting room became an informal art gallery. Because of this, a larger population came into regular contact with Dashwood's image as St. Francis of Wycombe. The consequences of continuous public contact with Dashwood's painting were described by John Wilkes. He described Dashwood's portrait (fig. 5), which had continuously hung at the King's Arms from 1742 to 1757 before it was transferred to the society's new home at the Star and Garter: ${ }^{71}$

There was for many years in the great room, at the king's arms tavern, in Old Palaceyard, an original picture of Sir Francis Dashwood, presented by himself to the Dilettanticlub. He is in the habit of a Franciscan, kneeling before the Venus of Medicis, his gloating eyes fix'd, as in a trance, on what the modesty of nature seems most desirous to conceal, and a bumper in his hand, with the words MATRI SANCTORUM in capitals. The glory too, which till then had only encircled the sacred heads of our Saviour and the Apostles, is made to beam on that favourite spot, and seems to pierce the hallow'd gloom of maidenhead thicket. The public saw, and were for many years offended with so infamous a picture, yet it remain'd there, till that club left the house. ${ }^{72}$

\footnotetext{
${ }^{69}$ Charles de Brosses, Lettres d'Italie du Président de Brosses, vol. 2 (Paris, 1986), 445. It is possible that this is the earliest reference to what would eventually become the Medmenham Monks. On 5 October 1745 (Bodleian MS D.D. Dashwood [Bucks] C.5 B11/1/5, lr), George Bubb Dodington wrote to Dashwood about a small group that met at Dashwood's residence, "I must confess, I never mett with more Improvement, as well as Entertainment, in so small a Company; \& do verily believe, there are as many Sallies of true Witt, \& Humour in Them, as most of the Societies in Town, which most pretend to Both can boast of."

${ }^{70}$ SDSM, 4 January 1741. For an analysis of Knapton's Dilettanti paintings as a group, see Bruce Redford, “'Seria Ludo': George Knapton's Portraits of the Society of Dilettanti," British Art Journal 3, no. 1 (2001): 56-68, and West, "Libertinism and the Ideology of Male Friendship."

${ }^{71}$ The Society moved its room to the Star and Garter Tavern in May 1757. See SDSM, 1 May 1757.

${ }^{72}$ Reprinted in A Select Collection of the Most Interesting Letters on the Government, Liberty, and Constitution of England, vol. 2 (London, 1763), 37. This was an extension of [John Wilkes], Public Advertiser (2 June 1763).
} 


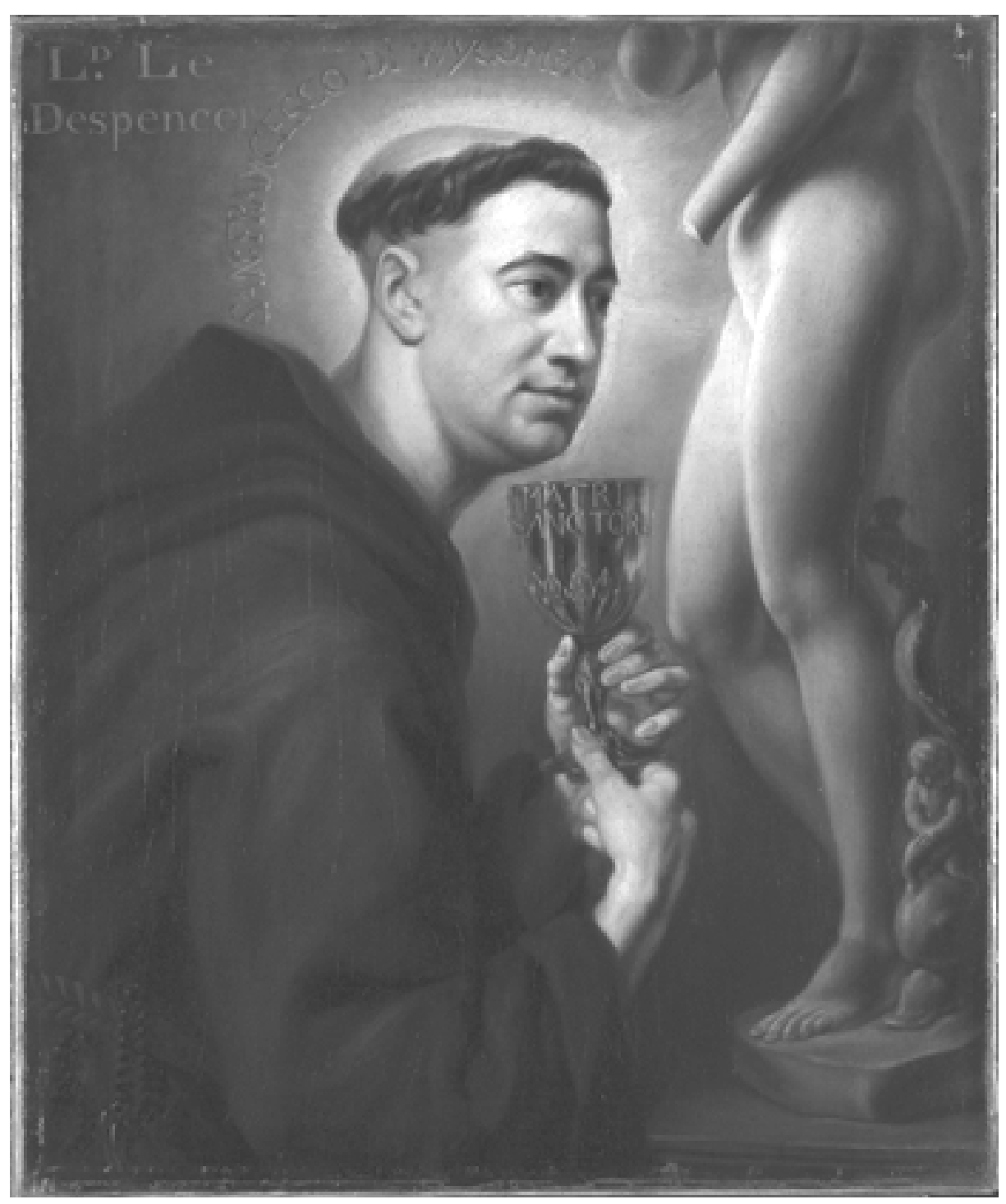

Figure 5-George Knapton, Sir Francis Dashwood, 1742. Society of Dilettanti. Photograph: Photographic Survey, Courtauld Institute of Art. Color version available as an online enhancement.

Consequently, the lascivious and antireligious connotations of this painting caused Londoners to confuse the activities of the Dilettanti with the private lives of its members. Even Horace Walpole, typically in the know, succumbed to conflating the Dilettanti and the Order of St. Francis, writing that Dashwood's club was a "more select order" of Dilettanti: "These pictures were long exhibited in their club room in Palace Yard; but of later years St. Francis had instituted a more select order. He and some chosen friends had hired the ruins of Medmenham 
Abbey near Marlow." ${ }^{\prime 3}$ While other members of the Dilettanti remained silent on the matter throughout the 1740s and 1750s, Middlesex, Dashwood, and Sandwich reveled in this association. In fact, they sponsored other images of their less reputable activities. In 1757, Dashwood commissioned William Hogarth to mimic Knapton's painting in a second portrait of himself as St. Francis (fig. 6). Sir Francis Dashwood at His Devotions probably hung behind curtains in Dashwood's salon, only to be exhibited to his male friends and visitors-initially as a pornographic jest for the private amusement of his gentlemanly associates. But, in 1760, Dashwood had it engraved for a larger audience. Based on the themes in Knapton's portrait, the kneeling Francis ogles an antique figure, which has transformed into a naked, prostrate woman, and, in Wilkes's words, Dashwood stares "on what the modesty of nature deems most desirous to conceal." ${ }^{74}$ The nimbus over his head is the profile of the Earl of Sandwich. An open book, probably referring to the poems of Ovid, and a masquerade mask lie nearby as a tray of fruits and wine tumbles to the floor, referring the viewer to the excess of Carnival and the attendant rites of Bacchus and Venus, which the men had experienced on the Grand Tour.

Thus, the men who were involved with the Order of St. Francis were cavalier about their activities. In fact, they took pleasure in the notoriety-good and badthat their excesses garnered. For example, Paul Whitehead's membership in the Medmenham Monks is one of the reasons that Boswell gives for Samuel Johnson's dislike of the poet. ${ }^{75}$ John Wilkes was proud to claim that he had slighted (for a second time) William, Lord Talbot, by postponing their duel because of a hangover that he had incurred at Medmenham. Writing to Richard Grenville, Earl Temple, on 6 October 1762, the day after the duel actually took place, Wilkes wrote about his sarcastic exchange with Talbot: "I was come from Medmenham Abbey where the jovial monks of St. Francis had kept me up till four in the morning, that the world would therefore conclude I was drunk, and form no favourable opinion of his lordship from a duel at such a time." 76 Temple's response suggests familiarity with the group and that Wilkes's behavior in this incident was a confirmation of his masculinity: "Firmness, coolness, and a manly politeness, makes up the whole of this transaction on your part . . I was sure you would extricate yourself like a man." 77

By the time Wilkes printed Secrets of a Convent, many of his supporters had heard some information about Medmenham, which, in addition to the club's members and their associates, was probably spread to London by household servants, tavern keepers, and prostitutes ${ }^{78}$ Horace Walpole described the rumors about the club as public knowledge: "Whatever their doctrines were, their practice was rigorously pagan. Bacchus and Venus were the deities to whom they almost publicly sacrificed; and the nymphs and the hogsheads that were laid in against

\footnotetext{
${ }^{73}$ Horace Walpole, Memoirs of the Reign of King George III, vol. 1, ed. Derek Jarrett (New Haven, CT, 2000), 114

${ }^{74}$ Select Collection of the Most Interesting Letters, 37.

${ }^{75}$ James Boswell, Life of Johnson, ed. R. W. Chapman (Oxford, 1980), 91.

${ }^{76}$ Wilkes to Temple, 6 October 1762 , in Letters between Duke of Grafton . . . and John Wilkes, vol. 1 (London, 1769), 22-23.

${ }_{77}$ Temple to Wilkes, 6 October 1762, Grenville Papers, 1:478.

${ }^{78}$ Charles Johnstone (Chrysal; or, Travels of a Guinea, vols. 3-4 [London, 1764]) referred to the role servants had in spreading gossip about Medmenham.
} 


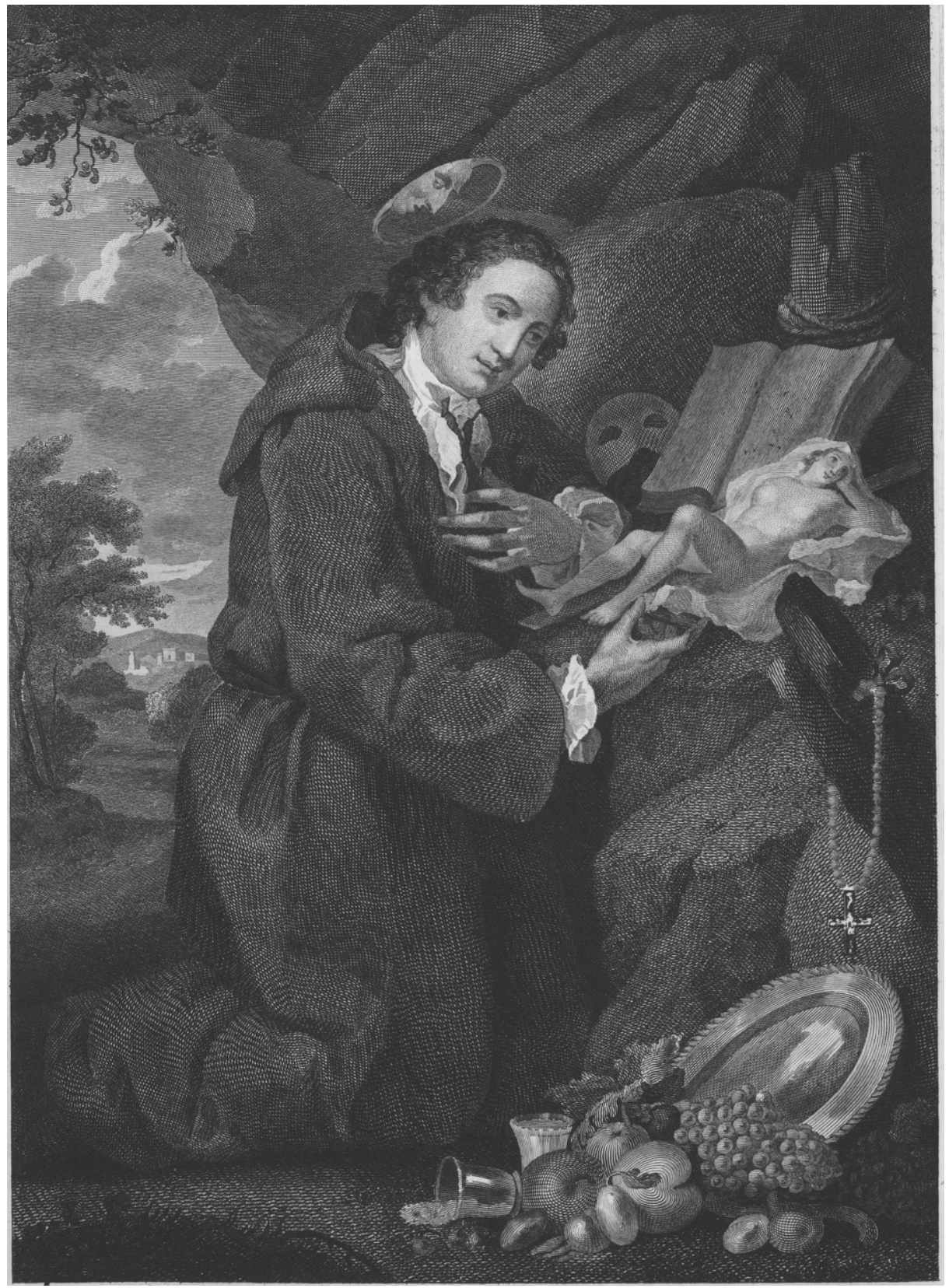

Figure 6-William Hogarth, Sir Francis Dashwood at His Devotions, 1757. (c) by the Trustees of the British Museum. 
the festivals of this new church, sufficiently informed the neighborhood of the complexion of those hermits." 79 Wilkes knew that he could catalyze these rumors among a large audience using the press, which is why he also advertised the print in the widely read Public Advertiser ${ }^{80}$ With a weekly subscription of at least 1,500 to 2,000 and a higher number of readers due to the London season, a conservative estimate suggests that 15,000-20,000 people knew about the print before it ever reached the streets. ${ }^{81}$ And, it is probable that at least 10,000 Londoners saw the print. $^{82}$

This reading public interpreted the iconography of the print in relation to the rumored meeting of the Order of St. Francis that held parties in the abandoned Cistercian abbey on Dashwood's estate. Generally, the story went thus: Francis Dashwood and his friends celebrated the rites of Bacchus in an anti-Catholic masquerade at West Wycombe. The definitive features of their meetings were the reading of pornographic literature, the consumption of alcohol, and the hiring of prostitutes. Dashwood was well known for his love of the antique, having experienced a memorable Grand Tour and serving as a prominent member of the Society of Dilettanti, and the presence of the Medici Venus in the print was both an allusion to his fascination with antiquities and his penchant for womanizing. For those who had seen Knapton's painting in Pall Mall, the image was already familiar. In the print, while the poet Paul Whitehead attempts to remind Dashwood of the history of St. Hubert, a courtier known for his mannerly conduct and who later gave away his possessions, Dashwood points to his chalice of wine. The book on the altar reads "PRECES VESPERIVE," or "evening vespers," antireligious prayers as revealed by the accompanying text, "VOX IN DEUM CONTUMELIOSA," or "a voice abusive towards God." Above their heads is Cicero's lamentation, "O TEMPORA O MORES," or "alas for the times and manners." ${ }^{\text {" T3 }}$ The poem beneath Wilkes's print reads:

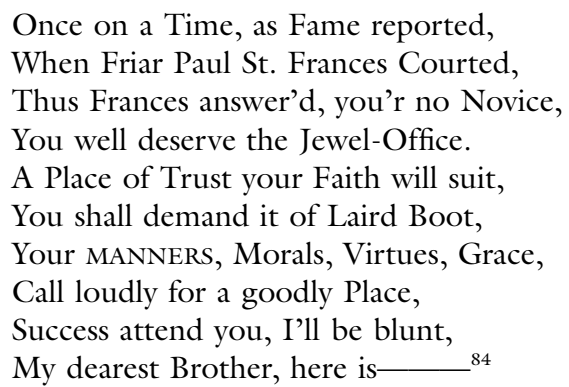

The poem alludes to Dashwood's patronage of the roguish and allegedly republican Whitehead, whom Dashwood had appointed deputy treasurer of the chamber in 1761 and who now held an important place in the reputed meetings of the Monks

\footnotetext{
${ }^{79}$ Walpole, Memoirs of George III, 114.

${ }^{80}$ Public Advertiser, no. 8806 (22 January 1763): 2r.

${ }^{81}$ Brewer, Party Ideology and Popular Politics, 143.

${ }^{82}$ This is estimating a print run of 500 prints, with twenty readers per print.

${ }^{83}$ Cicero, Orationes in Catilinam 1.1.2.

${ }^{84}$ Secrets of a Convent (London, 1763).
} 
of Medmenham. ${ }^{85}$ The theme of sexuality pervades the print, most notably in the unabashed final couplet. However, the "Hymns of Ovid" and a book of popular drinking songs at the foot of the altar are also suggestive. Dashwood and his friends were renowned for their lewd verses. Considering Walpole's suggestion that London audiences had a good deal of knowledge - credible or not-about Medmenham, the inclusion of these texts within the image suggest popular rumors about a bawdy library at Medmenham, which would later be confirmed in the newspapers.

When considered by eighteenth-century conventions of gentlemanly association, these activities were hardly beyond the pale of acceptable behavior. However, following Anna Clark's thesis about the "neo-Lockean" rhetoric of Wilkite critique as an attack on private influence over public policy, historians can read the Secrets of a Convent as a political critique-in the vein of the North Briton-rather than a moral critique. ${ }^{86}$ Wilkes represented Dashwood as distinct from the average citizen, with access to power, patronage, and wealth. He is distracted by his hobbies, and, if not corrupt, then certainly unfit to manage the finances ${ }^{87}$ Whitehead was even more despicable, for as Wilkes wrote of him a few months later, "He, who was ever a licentious assertor of privileges, whose tongue was loudest in every mob to resound their rights, and to vindicate the liberty of the press; who treated nobles with impunity ... shall he become a defender of the base, infamous doctrine of passive obedience and non-resistance?" ${ }^{\prime 8}$ Wilkes was repelled, but not surprised, by Dashwood's "court Jacobit[ism]," and he was offended by Whitehead's abandonment of "staunch republicanism" for an appointment to deputy treasurer of the chamber. ${ }^{89}$

In all, popular rumors about Medmenham allowed Wilkes to use them for his political agenda. He would not have produced this print-and certainly could not have sold it-unless there was a popular literacy about its content. The political affairs at court, reported by the press, and their relation to the private lives of London's most notorious libertines, disseminated through gossip and rumor, became central to Wilkite rhetoric and symbolism throughout 1763.

While the public's initial reaction to Secrets of a Convent was minimal, by spring, the stories about Medmenham took on added significance, as Wilkes's political troubles increased. Wilkes and forty-eight others were arrested on 30 April 1763 under a general warrant for the alleged seditious and libelous North Briton no. 45. His release on 3 May by Lord Chief Justice Pratt signaled the beginning of the "War of the Quills," a pamphlet war between Wilkes and his enemies. ${ }^{90}$ This time, the public's perception of Medmenham became central to his argument. In May, Wilkes began publishing stories that again alluded to the rumored activities of Medmenham, most notably prostitution and pornography. By June, he began

\footnotetext{
${ }^{85}$ Wilkes and Churchill were scathing in their attacks on Whitehead's abandonment of principal for patronage. See North Briton, no. 44 (2 April 1763).

${ }^{86}$ Anna Clark, "The Chevalier d'Eon and Wilkes," 29.

${ }^{87}$ The print is also critical of Whitehead, who, despite critiquing the courtiers in earlier poetry, accepted a post from Dashwood.

${ }^{88}$ John Wilkes, North Briton, no. 44 (2 April 1763), 219.

${ }^{89}$ Ibid. Whitehead became deputy treasurer in 1761 and deputy keeper of the wardrobe in 1763 , following the fall of Bute and Dashwood's new position as master of the wardrobe.

${ }^{90}$ Cobbett and Howell, State Trials, 981, 989-90.
} 
a new approach, publicly associating himself with the group. From his firsthand experience, he confirmed the rumors about the Order of St. Francis in print. Thus, he was able to act as an informant, transforming what had formerly been unsubstantiated rumor into salacious gossip in a printed dialogue that took place among him, his supporters, and even his enemies.

Referring to the seizure of his property by the government on 30 April, Wilkes published a satirical piece in the Public Advertiser on 20 May 1763. This story was restated in several other newspapers. Speaking of himself in the third person, he claimed that the government had stolen, among other things, "Some obscene Prints" and "One dozen of Mrs. Phillips's Purses." "11 Astute readers would have recognized that the dozen condoms and the "obscene prints" were linked to the activities of Medmenham. However, for those readers who did not make the connection, he clarified it on 25 May in a letter to the Public Advertiser's editor:

I DARE say some of the curious Articles in the Inventory . . . which were carried to the Secretary of State's Office, have been imported by that Gentleman . . . to compleat the valuable Collection of that Sort, which is in the Salloon of the famous CONVENT on the Banks of the Thames, call'd Medmenham Abby, where the Right Hon. the Lord LE DESPENCER presides with so much Decency and Order, and has spent many a jovial Day with Mr. WILKES before their late Difference in Politics. It is hoped his Lordship's Interest will be able to procure a Restitution of the Goods to Mr. Wilkes, or a Grant to the Abby of the Forfeiture, upon Mr. WILKEs's Conviction, that the Members of that noble Institution may not be injured by the Offence of a Brother. $^{92}$

An article by Wilkes in the 2 June 1763 edition of the Public Advertiser included an extended description of Dashwood's estate. He hinted at secret “convivial Rites" within the steeple of the local church as well as "jolly Songs, very unfit for the profane Ears of the World below." ${ }^{93}$ He explained that the gardens at the estate were covered in sexual imagery, including explicit statuary and other suggestive garden conceits, but coyly added: "[T] he Description [of Medmenham Abbey] ... I thought might entertain you; but I am too fair a Man to disclose to the Public the English Eleusinian Mysteries of that renown'd Convent." Wilkes, a selfproclaimed member of the group, confirmed the rumors that had existed for years, but as usual he left the reader hungering for more details. ${ }^{94}$

${ }^{91}$ Public Advertiser, no. 8905 (20 May 1763): 1r.

${ }^{92}$ Public Advertiser, no. 8909 (25 May 1763): 1v.; repr. in Saint James's Chronicle; or, the British Evening-Post, no. 347 (26 May 1763): 2r.

${ }_{93}$ Public Advertiser, no. 8914 (2 June 1763) lv.; repr. in Saint James's Chronicle; or, the British Evening-Post, no. 351 (4 June 1763): 1r.

${ }^{94}$ This tactic was noted by The Annual Register . . f for the Year 1764 (London, 1765), 19, 24. The anthropologist Paul Christopher Johnson (Secrets, Gossip, and Gods: The Transformation of Brazilian Candomblé [Oxford, 2002]) has recently demonstrated how effective this technique-what he calls secretism - is in generating more rumor. He writes: "Secretism I define as not merely reputation, but the active milling, polishing, and promotion of the reputation of secrets. Secretism is freely and generously shared. Secretism does not diminish a sign's prestige by revealing it, but rather increases it through the promiscuous circulation of its reputation. . . . It is through secretism, the circulation of a secret's inaccessibility, the words and actions that throw that absence into relief, that a secret's power grows, quite independently of whether or not it exists" (3). 
Meanwhile, Wilkes prepared 2,000 copies of the entire North Briton series at his private press on St. George Street and began circulating them throughout the city. ${ }^{95} \mathrm{He}$ also began printing twelve copies for his friends of a poem titled Essay on Woman, a line-for-line pornographic parody of Pope's Essay on Man.$^{96}$ At some point during the late spring or summer, the government became aware of the Essay on Woman. In August, the solicitor for the treasury, Philip Carteret Webb, worked with Sandwich, the recently appointed secretary of state, to bribe and threaten Wilkes's printer, Michael Curry, into handing over a proof copy of the first part of the Essay. Sandwich hoped to condemn Wilkes's pornographic poem in the upcoming session of the House of Lords. However, Lord Chancellor Henley advised him that the subject of the poem was inappropriate for the house. And, after all, publishing pornography was not necessarily illegal, even though pornographic works were sometimes prosecuted as obscene libel or blasphemy. The two men resolved the issue by agreeing that Sandwich would not bring "the matter before the house merely as a blasphemous and impious work." Rather, it would be "brought as a complaint on account of the improper mention of the name of a peer [William Warburton, bishop of Gloucester]." ${ }^{97}$ In November, Sandwich brought his complaint to the House of Lords, and the story of the writing, confiscation, and prosecution of the Essay on Woman soon became public knowledge. ${ }^{98}$ At the same time, the House of Commons continued its prosecution of Wilkes's North Briton no. 45. The government found Wilkes guilty of libel for publishing the North Briton no. 45 and the Essay on Woman, but before they could arrest him, he slipped away to Paris, becoming an outlaw.

Throughout the summer of 1763, the call of the London masses was "Wilkes and Liberty!" but, specifically, liberty referred to freedom from arbitrary arrest. When Parliament assembled in November 1763, the Wilkite cause became an even broader political issue. Sandwich's decision to prosecute Wilkes for the Essay on Woman was a political miscalculation. He misread the political symbolism of his act, which seemed hypocritical to his peers and an outright act of tyranny to Wilkes's followers. Sandwich supposed that his attack would finally discredit Wilkes, but he misjudged the extent of public knowledge about Medmenham and expectations about private friendship and political conduct.

As revealed above, the stories about Medmenham consistently referred to a corpus of private literature, the existence of which was probably more widely known than historians have surmised. In fact, The Essay on Woman was only one of a number

\footnotetext{
${ }^{95}$ Wilkes to Temple, 9 July 1763, Grenville Papers, 2:75.

${ }^{96}$ Rudé, Wilkes and Liberty, 31. In Wilkes to Temple, 26 July 1763, Grenville Papers, 2:81, Wilkes claimed that he had no intention of publishing the Essay on Woman.

${ }^{97}$ Sandwich to George Grenville, 5 November 1763, Grenville Papers, 2:154.

${ }^{98}$ See, e.g., Public Advertiser, no. 9062 (18 November 1763): 1r, and no. 9070 (28 November 1763): 1r-2v. Several pamphlets published in late 1763 summarized the copious correspondence in the newspapers. These include John Kidgell, A Genuine and Succinct Narrative of a Scandalous, Obscene, and Exceedingly Profane Libel (London, [1763]), two editions; [John Almon], A Letter to J. Kidgell, Containing a Full Answer to His Narrative (London, 1763), three editions; see also An Expostulatory Letter to the Reverend Mr. Kidgell (London, 1763), three editions; and A Priest in Rhyme (London, [1763]). Arthur H. Cash (An Essay on Woman by Jobn Wilkes and Thomas Potter [New York, 2000], 61, 69-73) and Adrian Hamilton (The Infamous Essay on Woman, or John Wilkes Seated between Vice and Virtue [London, 1972], 246) convincingly argue that Sandwich printed a "government edition" of the Essay on Woman for circulation in the House of Lords.
} 
of privately circulating erotic poems composed, exchanged, and read by club members. ${ }^{99}$ of poems is contained in a manuscript at the William Andrews Clark Memorial Library titled Eros in Monachium. It includes poems written by the monks-Wilkes, Churchill, Dashwood, Sandwich, Potter, and others-during the 1750s and early 1760s. ${ }^{100}$ The manuscript, containing numerous poems and several prose pieces, were part of "a few hundred bawdy songs . . . [and] some very respectable Verses" composed at Medmenham. ${ }^{101}$ In these texts, the men praise their sexual prowess and human anatomy, as well as their mistresses and lovers, including Elizabeth Chudleigh and Maria Gunning. For example, a poem titled "D[ashwoo]d's Lost Cod-Piece (A Tragedy)" states that things like hell and ghosts

Twold not thee half so much affright

As this dread Story of a Spright

Who came to $\mathrm{D}-\mathrm{d}$ in the Night

And sliced away his Codpiece quite

Oh sliced it off, yea inch by inch

No more need Maids and Matrons flinch! ${ }^{102}$

Karen Harvey has contextualized Eros in Monachium, arguing that its composition by members and its readings at Medmenham were central to creating an environment of homosocial convivium. ${ }^{103}$ In other words, members cemented their friendly bonds through the masculine, sociable activity of creating and reciting erotica, and, in fact, sexual behavior and desire was ostensibly dissociated from the act of conversation. ${ }^{104}$ While there is little doubt that these private readings reinforced friendships, a complete separation from sexuality is unlikely in the Medmenham context. Rather, the tenuous balance of polite conviviality and masculine libertinism at Medmenham further underlines shifting modes of acceptable gentlemanly social conduct during this period. The Essay on Woman, probably composed by Thomas Potter and John Wilkes during the 1750s, fits neatly into the mold of these other Medmenhamite verses. ${ }^{105}$

When Sandwich stood in the House of Lords to read and condemn the poem, many peers were shocked. Dedicated to Fanny Murrray, Sandwich's well-known former lover, the poem begins with an invitation for a libidinous rendezvous:

Awake, my Fanny, leave all meaner things,

This morn shall prove what raptures swiving brings. ${ }^{106}$

\footnotetext{
${ }^{99}$ In addition to manuscript literature, Medmenham housed printed works, including Le Cabinet d'Amour et de Venus (Cologne, n.d., British Library, CUP.800.a.48) and others still in the collection of the Dashwood family. See Cash, Essay on Woman, 28 n. 62.

${ }^{100}$ The book was property of John Campbell, Baron Sundridge of Coombank, a heretofore unknown member of the club.

${ }^{101} \mathrm{P}$ [aul] W[hitehead] and T[homas] P[otter], [et al.], "Eros in Monachium or the Medmenham Garland Cull'd from the Franciscan Originals" (William Andrews Clark Memorial Library MS E71MI),

lv. The poetry ranges from Charles Churchill's accomplished interpretation of the Song of Solomon to Wilkes's own "Solomon's Song. A la Mode de Hudibras."

${ }^{102}$ Ibid., 60v.

${ }^{103}$ Karen Harvey, Reading Sex in the Eighteenth Century: Bodies and Gender in English Erotic Culture (Cambridge, 2004), 60-68.

${ }^{104}$ Ibid., 223.

${ }^{105}$ On the debate over attribution, see Cash, An Essay on Woman.

${ }^{106}$ Ibid., 97.
} 
However, the surprise of Sandwich's audience had as much to do with his own reputation as the content of the poem. As Walpole recounted, everyone knew that Sandwich's attack was "revengeful . . . totally unconnected with the political conduct of Wilkes." ${ }^{107}$ Moreover, it dripped with insincerity. Sandwich's own proclivities for "singing profane and lewd catches" were unmatched, even by Francis Dashwood. ${ }^{108}$ Many of the peers already knew that if Dashwood and Sandwich had not had a hand in writing the poem, they had at least celebrated the poem's composition. In fact, a number of people within London had similar thoughts.

Within weeks, the newspapers were buzzing with news of Sandwich's reading as well as his hypocrisy. For example, the St. James's Chronicle printed the following poem:

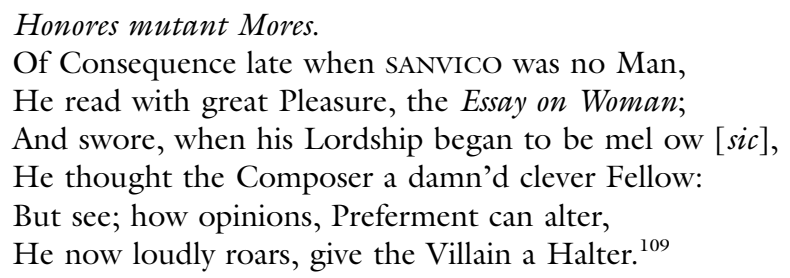

Writers increasingly referred to Sandwich as "pious" or, more commonly, as "Jemmy Twitcher," an allusion to the betraying thief in John Gay's Beggar's Opera. One poem read:

THAT Jemmy Twitcher should his Comrade peach, And against Vice, like Parson Tartuffe, preach; ${ }^{110}$

In all, the reading public was aware of Sandwich's duplicity. The papers were quick to link the Essay on Woman to the activities and symbolism at Medmenham:

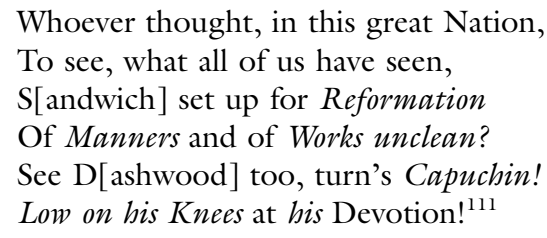

The press also associated the Dilettanti with Medmenham activities. Reminding the readers of Knapton's painting of Dashwood as "San Francesco de Wycombo," the St. James's Chronicle explained the lines "See D[ashwood] too, turn's Capuchin! / Low on his Knees at his Devotion!" thus: Alluding to a Picture in the D-1-tante Club-Room, at a Tavern, in New Palace-Yard, drawn in that Dress, and in a Posture of Adoration before the Virgin, with an Inscription over it, Mater

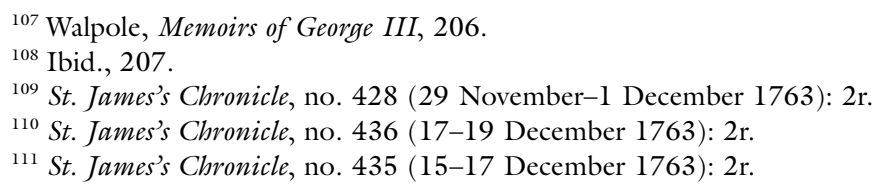


Sanctorum; this Club always met on a Sunday, and these two most religious Personages were both Members of it." 112

While London readers were excited by the sexualized gossip-in fact, several unauthorized and imaginative versions of the Essay on Woman were being sold in London-the underlying political rhetoric suggested that Wilkes's "companions of his hours of mirth and jollity" had turned "traytors to the most sacred of all human ties, private friendship, and inform for prosecution what was whispered as a bosom friend." 113 In other words, there had been a betrayal of private confidence for public gain. Moreover, Wilkes claimed that his fellow monks, "the greatest personages in this kingdom," "not only knew that there was such a work in being six or seven years ago, but that they themselves assisted in putting it together." He claimed to have begun printing copies of the work for these men's "own private conversation; and meant as a mere joke among themselves." 114 Sandwich's attack on Wilkes was the hypocritical twist to the Medmenham saga. For, even though Wilkes may have written a pornographic poem, the events portrayed within it were wholly associated with Sandwich-now known as the notorious Jemmy Twitcher-who came to represent the arbitrary, vindictive, and corrupt hand of the government. ${ }^{115}$ Among Londoners, Sandwich, Dashwood, Medmenham—and, by default, the Society of Dilettanti-became symbolic points of reference for Wilkes's plight. Sandwich's attack in the House of Lords represented the betrayal of a libertine code of conduct, which, while reveling in public rumor, did not make private activities a matter of political debate, as long as private activities did not corrupt public conduct. At the same time, a gentlemanly code of honor proscribed the betrayal of confidence and friendship, an act as offensive to Wilkite supporters as arbitrary arrest and seizure of goods. According to Walpole, by making Wilkes's private conduct a matter of public debate, Sandwich "brought a stigma on himself" that only "the rank and fortune of Sandwich saved him from disgrace." 116

Wilkes capitalized on the politicization of the Medmenham stories. From his exile in Paris, he fed his friends John Almon and Charles Johnstone narratives about the Order of St. Francis. Likewise, Charles Churchill published damning accounts in a series of poems about the members. In these sometimes dramatic, occasionally erotic, and increasingly sensational stories, Medmenham became a microcosm of the political affairs of 1763 . Wilkes could be assured that his former friends' perfidy would be remembered in the gossipy talk and rumor-driven innuendo about town. The stories-functioning as a folkloric memory of sortswould take on their own lives and keep the memory of Wilkes's political betrayal fresh.

In the first months of 1764 , Wilkes continued his attacks from the relative safety

\footnotetext{
${ }^{112}$ Ibid.

${ }^{113}$ Public Advertiser, no. 9072 (30 November 1763): 2r. The spurious 1763-64 versions of the Essay on Woman include: Essai sur la femme ([Amsterdam], [1763]); An Essay on Woman, in Three Epistles ([London], [1763]); An Essay on Woman, a Poem by J. W. Senator ([London], [1763]); An Essay on Woman ([London], 1764).

${ }^{114}$ Public Advertiser, no. 9073 (1 December 1763): 2r, and see also no. 9078 (7 December 1763): 2r, and no. 9083 (13 December 1763): 2r.

${ }^{115}$ Walpole, Memoirs of George III, 207.

${ }^{116}$ Ibid.
} 
of Paris. ${ }^{117}$ Charles Churchill aided his friend in a bitter assault on Sandwich. Churchill's verse polemic, The Candidate, made sure to include a reference to Medmenham:

\author{
Whilst Womanhood, in habit of a Nun, \\ At M[edmenham] lies, by backward Monks undone; \\ A nation's reck'ning, like an alehouse score, \\ Whilst PAUL the aged chalks behind a door, \\ [Dashwood], shall pour, from a Communion Cup, \\ Libations to the Goddess without eyes, \\ And $\mathrm{Hob}$ or Nob in Cyder and excise. ${ }^{118}$
}

The poem was so admired that it went through two printings in 1764 .

Still, the most popular description of the Medmenham Monks was in Charles Johnstone's Chrysal; or, Travels of a Guinea. ${ }^{19}$ Fed with information from Wilkes, Johnstone both confirmed rumors and added more fodder to the gossip networks. In Chrysal, the Order of St. Francis dressed up as monks or friars, "in a burlesque imitation of the religious societies." "20 After dining and drinking to excess, the men would retire to their "cells" where they would entertain prostitutes, or "nuns" as they were often called in the period. ${ }^{121}$ When sex and alcohol were not on the menu, the men enjoyed participating in perverse mimicry of religious ceremonies under a canopy of Josephi Borgnis's sexually explicit paintings and wall coverings. ${ }^{122}$

The participants, Johnstone claimed, belonged to one of two orders, a higher or a lower. Only twelve men could serve in the higher order, and when one died or left the club, a member from the lower order replaced him. At some point in the brotherhood's history, Wilkes and Sandwich allegedly came into competition for a place in the primary order, which Wilkes lost because of his competitor's "higher rank in life." 123 Johnstone wrote that Wilkes decided to have his revenge on Sandwich's promotion by retaliating with coarse, prankish behavior. Sneaking a baboon into the "chapel," he dressed it up as a devil, and hid it in a chest. ${ }^{124}$ He later released it on his comrades in the midst of ceremony, frightening all of them "out of their senses," especially when the baboon leaped on Sandwich. ${ }^{125}$ Sandwich cried out in fear, "Spare me, gracious Devil! (said he) spare a wretch, who never was sincerely your servant! I sinned only from vanity of being in the fashion! thou knowest I never have been half so wicked, as I pretended; never have been able to commit the thousandth part of the vices, which I have boasted of. Take not then the advantage of that vanity; but judge me only from my

\footnotetext{
${ }^{117}$ See, e.g., "A Letter from Paris," London Magazine; or, Gentleman's Monthly Intelligencer, February $1764,256-57$

${ }^{118}$ Charles Churchill, The Candidate (London, 1764), 33.

${ }^{119}$ Johnstone, Chrysal.

${ }^{120}$ Ibid., 231.

${ }^{121}$ Ibid., 233. Horace Walpole (Journals of Visits to Country Seats [July 1759-September 1784] [1928; repr., New York: Garland, 1982], 50) also spoke of "nuns" in his description of "Mednam abbey near Marlow" in 1763.

${ }^{122}$ Johnstone, Chrysal, 234.

${ }^{123}$ Ibid., 240.

${ }^{124}$ Ibid., 240-41.

${ }^{125}$ Ibid., 241-42.
} 
actions." ${ }^{26}$ Once everything finally settled, the baboon escaped out the window, and the men recovered their composure. Sandwich, driven by a rage of embarrassment, convinced his friends to ban Wilkes from the club. ${ }^{127}$ In this incident, Sandwich is again portrayed as delighting in his wanton reputation. This could be seen as a parable of the events of 1763 . Wilkes was betrayed by his closest friends, who, because of their position in life, were able to exile him from their midst. As in life, Wilkes sins against his betters, not for any real infraction, but because of his inability to take their stations seriously.

The circulation of stories like those in Chrysal found a ready audience by 1764, and a series of similar publications followed soon thereafter. In 1768, Wilkes returned from exile only to be imprisoned as an outlaw. This set off another round of Medmenham publications. Between 1763 and 1768, the rumors about Medmenham - its libertines, its secrets, and its betrayals — had become a central element of Wilkite rhetoric. The rumors and gossip surrounding the Monks of Medmenham Abbey, which had been such an important element of gentlemanly libertinism in the 1750s, now served to boost the popular cause of "Wilkes and Liberty!" and, in effect, undermine the reputations of Dashwood, Sandwich, and their associates. ${ }^{128}$

\section{CONCLUSION}

The Calves-Head Club and Medmenham Monk stories help illustrate the significance of rumor and gossip to eighteenth-century society and politics. While rumor and gossip were not necessarily synonymous with the Grub Street press, we can, however, read between the lines to discover the common knowledge of the London middling orders and, sometimes, even the London street. The reputations of the libertines, the pleasure they took in their activities, and the circulation of stories about them depended on the participation of a much larger group of people than their friends and peers. Londoners, particularly the middling sorts, were an important audience for overt, aristocratic displays of masculinity. It was against this audience that the libertines framed themselves, for these activities were only for men of rank. However, to an extent, Londoners also participated in these displays of masculinity and social status. As an audience, they were essential to the properly performed rites of the libertine, playing integral roles by circulating and embellishing stories.

When actor and audience played their roles properly, a balance could be maintained between uncivil recreation and polite society, between gentlemanly license and a publicly feigned disgust that belied private enjoyment. The public tolerated a level of immorality and social excess that it deemed, if not appropriate, then allowable for men of certain rank. Additionally, their gossip and rumor patrolled the boundaries of acceptable middling civility even while they experienced the pleasures of gossip. Libertines also practiced an unwritten code of behavior. Their

\footnotetext{
${ }^{126}$ Ibid., $242-43$.

${ }^{127}$ Walpole (Journals of Visits to Country Seats, 50) believed the order banished Wilkes for his attack on Dashwood in North Briton.

${ }^{128}$ See, e.g., A Letter of Advice from Alma Mater to Her Beloved Son Jemmy Twitcher (London, 1764); John Almon, ed., New Foundling Hospital for Wit (London, 1768-84); [John Hall Stevenson], Makarony Fables (London, 1768); and Town and Country Magazine l (1769): 122.
} 
activities bolstered their status by serving as signifiers of a separate code of gentlemanly rights - rights that were, in fact, held in check by gossip and rumor. Yet, their dalliances with Bacchus and Venus could not slip the bounds of an ostensibly private association without the possibility of dramatic political consequences of such as those of 1763.

What created the problem for the Medmenham group and the Dilettanti in 1763 was that they dealt with public gossip and rumor differently than in 1734/ 5 . In both incidents, a group of aristocrats and gentlemen catalyzed preexisting gossip networks. Likewise, in both cases, the men misread popular sentiment when responding to an audience already enraged by their gaffes. The result was a riot and several weeks of Grub Street exaggeration. In the Calves-Head incident, the men reacted immediately through letters to the rumors that their meeting was antimonarchical, but they did not engage with the press or attempt to defend their reputations publicly. The Medmenham Monks and the Dilettanti of 1763 were not so fortunate. For decades, these men had cultivated their libertine reputations among the populace. They had, in fact, created and nurtured the gossip and rumor about their meetings. When Wilkes sought to attack his foes, prints such as Secrets of a Convent and the letters in the Public Advertiser and St. James's Chronicle served to critique them for corruption stemming from private influence and betrayal. In other words, Wilkes kept his political attacks and his personal attacks ostensibly separate. Dashwood, Grenville, and, particularly, Sandwich conflated the two in their rush to undermine Wilkes by condemning the Essay on Woman in a session of Parliament, which politicized libertine behavior and sparked public anger.

The politics of gossip and rumor add insight into our knowledge of eighteenthcentury associational life, and vice versa. In recent years, there has been an emphasis on "politeness" in the eighteenth-century public sphere, and while these studies have been fruitful, it is important to remember that politeness was more of an ideal than a norm. London street life, from the poorest navvy to the wealthiest earl was a dirty, dangerous, and volatile business. We need only remind ourselves of the number of riots, duels, brothels, and prostitutes that were juxtaposed with the "spaces of modernity" such as coffeehouses, taverns, and gardens. ${ }^{129}$ Furthermore, the boundaries of polite behavior depended on constantly shifting ideas about social rank.

Associational life also serves as a reminder of the complex functions and practices of gossip and rumor. For the self-representation of the libertine-with its semipornographic jests, its rowdy misbehaviors, and its antipolite license-a single activity could both bolster and undermine social status and gender constructs, depending on its context. It was the same for a corporate reputation, which, for the eighteenth century, was an important facet of gossip and rumor. For example, rumors about the Medmenham Monks nurtured their reputations for the masculine libertine's antivirtues of sexual prowess and drunken revelry. This was because the existence of Medmenham - its purpose perhaps-depended on its members' breaches of civil decorum. Their so-called private meetings relied on an audience and the circulation of stories in London.

However, the Society of Dilettanti, while nurturing an underbelly of libertinism

${ }^{129}$ See Miles Ogborn, Spaces of Modernity: London's Geographies, 1680-1780 (New York, 1998). 
within the confines of its meetings, had a more complex and multidimensional function to play in British society, especially by the 1760s. The Dilettanti became a specifically Enlightenment form of gentlemanly association that valued knowledge — both classical and modern—as a parallel to libertinism. In fact, their pursuit of knowledge fulfilled similar functions to that of libertinism. For example, it preserved their social status by privileging leisured study, collecting, and the patronage of scientific and artistic endeavors such as archaeological expeditions, the formation of the British Museum's collections, and the foundation of the Royal Academy. The Dilettanti's promotion of the arts and sciences in Britain allowed them to distance themselves from the public's association of the group with Middlesex, Sandwich, and Medmenham, all the while maintaining their libertine identity through alcohol-laden meetings (in a moment of indulgence in 1778, the Dilettanti banned coffee and tea from the dinner table) and sexually suggestive in-jokes. ${ }^{130}$ By the 1760s, and more specifically after 1763 , members of the Society of Dilettanti made a concerted effort to create a corporate character distinct from the reputations of its individual members. It is not coincidental that when the society formed an archaeological expedition to Ionia in 1764, they emphasized its benefit for their reputation: "[It will] prove of great Utility to the Litterary World, and will redound to the honour of the Society; if properly executed."131 And, when the Society published the results of the Ionian expedition in 1769, they explained that despite their private indulgences, the Society itself had not abandoned its duty to the public:

As this Narrative professes the strictest Regard to Truth, it would be disingenuous to insinuate, that a serious Plan for the Promotion of Arts was the only Motive for forming this Society: Friendly and Social Intercourse was, undoubtedly, the first great Object in view; but while, in this respect, no Set of Men ever kept up more religiously to their original Institution, it is hoped this Work will show that they have not, for that Reason, abandoned the Cause of Virtù, in which they are also engaged, or forfeited their Pretensions to that Character which is implied in the Name they have assumed." 132

It was from this perspective-duty to the public good-that the Society of Dilettanti began to reshape its public persona as an organization after 1763. If the practices of the Dilettanti members explored the limits of "Friendly and social Intercourse" as individuals in tavern riots or at Medmenham, the Dilettanti's money and publications nevertheless acted to affirm their corporate commitment to the betterment of British society. The members increasingly avoided public notoriety for their libertine actions in the wake of the Wilkite scandals of the 1760s. The 1760s had shown that, when combined with the press, gossip and rumor were powerful forces in reproducing middling codes of civility. In response, by the 1770s, the Dilettanti had reinvented themselves and established themselves as the premier British institution for the scholarly study and publication of classical Greek antiquities. However, an unfortunate decision to publish An Account of the Remains of the Worship of Priapus in 1786 revived earlier associations with mas-

\footnotetext{
${ }^{130}$ SDSM, 4 February 1778.

${ }^{131}$ Society of Antiquaries, Society of Dilettanti Committee Minute Books, 6 March 1764.

${ }^{132}$ Society of Dilettanti, Ionian Antiquities, vol. 1 (London, 1769), ii.
} 
culine libertinism, which, in large part because of the Wilkes affair, most Londoners now linked to aristocratic excess and corruption. ${ }^{133}$ The tenuous balance between gentlemanly libertinism and middling civility that had been challenged through the events of 30 January $1734 / 5$ and those of $1763-a$ balance that had been negotiated in the discursive spaces of gossip and rumor-no longer existed by the 1780s, and Richard Payne Knight, the author of Priapus, attempted to recall the copies that the Dilettanti had distributed. If the age of the libertine had not yet ended, the activities of the libertine increasingly became an object of public political scrutiny, discussion, and controversy.

${ }^{133}$ Michael Clarke and Nicholas Penny, The Arrogant Connoisseur: Richard Payne Knight, 1751-1824 (Manchester, 1982); Richard Payne Knight, A Discourse on the Worship of Priapus and Its Connection with the Mystic Theology of the Ancients (London, 1786); Frank J. Messmann, Richard Payne Knight: The Twilight of Virtuosity (The Hague, 1974); G. S. Rousseau, "The Sorrows of Priapus: Anticlericalism, Homosocial Desire, and Richard Payne Knight," in Sexual Underworlds of the Enlightenment, ed. G. S. Rousseau (Chapel Hill, NC, 1987), 101-53. 